\title{
Influence of magnesium doping on microstructure, optical and photocatalytic activity of zinc oxide thin films synthesis by sol-gel route
}

Imene Ameur ${ }^{1 *}$, Boubekeur Boudine ${ }^{1}$, Mouloud Laidoudi ${ }^{2}$, Malak Khennoucha ${ }^{1}$, Valérie Brien ${ }^{3}$, David Horwat ${ }^{4}$, Miloud Sebais ${ }^{1}$, Ouhiba Halimi ${ }^{1}$.

1 Crystallography Laboratory, Physics Department, Faculty of Exact Sciences, Mentouri Brothers - Constantine 1 University, Route Ain El bey, Constantine 25000, Algeria

2 Assia Djebar Higher Normal School of Constantine, Ali Mendjeli Constantine, Algeria

3 Université de Nantes, CNRS, Institut des Matériaux Jean Rouxel, IMN, F-44000 Nantes, France.

${ }^{4}$ Université de Lorraine, CNRS, IJL, F-54000, Nancy, France.

*E-mail: imeneame@yahoo.com 


\begin{abstract}
The article deals with the effect of Mg dopant on the properties and the photocatalytic of $\mathrm{ZnO}$ films synthesized by the sol-gel technique onto glass substrates. It is found that $\mathrm{Mg}$ dopant has a strong influence on the microstructure and functional properties. The EDX analysis revealed that $\mathrm{Mg}$ had been incorporated into the $\mathrm{ZnO}$. Structural studies through XRD have shown that the deposited films are of hexagonal structure with a preferential growth along the c-axis and nanometer crystal size. According to $\mathrm{AFM}$ analysis; it is found that the roughness of $\mathrm{Mg}$-doped $\mathrm{ZnO}$ films increases with the $\mathrm{Mg}$ dopant. The film surface depicted wrinkles morphology as observed by ESEM. Optical investigations by spectrophotometry and photoluminescence revealed that as the Mg dopant is increased, the optical band-gap increases. Moreover, near band edge and visible emissions as probed by Photoluminescence can be manipulated by the Mg dopant, as their intensity increases and decreases, respectively. Finally, the photocatalytic activity for degradation of methylene blue is strongly improved all the more as the $\mathrm{Mg}$ content is increased.
\end{abstract}

Keywords: ZnO; Sol-gel; Roughness; Microstructure; Band-gap; Photocatalytic test. 


\section{Introduction}

Agro, paper and textile industries create effluents that are polluted with chemicals such as dyes, phenols, and pesticides. Some of these pollutants are recognized to be toxic and carcinogenic. Besides to that, they are not only harmful to the human but impact the ecosystem as well. Recently, society as well as regulatory authorities around the world, they became much interested in these chemicals due to their natural stability decomposition and their rising levels of by-products in the environment, mostly in water bodies. Unfortunately, the diversity of the available water treatment processes including adsorption, membrane filtration, and chemical treatment are insufficient to remove all the dyes. Conversely, these processes also create secondary contaminations like toxic gases and sludges that impose further treatment [1].

Moreover, the treatment of contaminated water with dyes and other organic compounds, photocatalysis based on nano-sized semiconductor photocatalysts is a recently emerging clean and cost-effective and elegant alternative for the treatment of water contaminated with dyes and other organic compounds [2]. The high photocatalytic performance of metal-oxide semiconductors, like titanium dioxide $\left(\mathrm{TiO}_{2}\right)$ and zinc oxide $(\mathrm{ZnO})$, not only benefits from utilizing the high photosensitivity of these materials, but also their non-toxic nature, low cost, and eco-friendly nature [1]. As the photoactivity of catalysts as well influenced by the microstructural and chemical characteristics such as crystalline quality, size distribution, particle size, shape, phase composition and specific surface area [3], their optimization can be based on a materials science approach through microstructure and composition manipulation.

Zinc oxide $(\mathrm{ZnO})$ is an interesting catalyst material [4] as a semiconductor able to efficiently generate stable electron-hole pairs at room temperature. It an n-type semiconductor with large band-gap energy of $3.37 \mathrm{eV}$ and high excitation binding energy $(60 \mathrm{MeV})$ making the exciton stable at room temperature [5]. Beside to that, it is also an attractive material as n-type semiconductor films in optoelectronic devices such as photodetectors [6, 7], solar cells [8], biosensors [9], gas sensors [10], and spintronic devices $[11,12]$. The stable phase at room temperature is the well-known hexagonal wurtzite structure of $\mathrm{ZnO}$ [13]. $\mathrm{ZnO}$ is also used in various other fields of applications such as optics, energy, chemistry, environmental applications [14, 15]. 
Furthermore, doping with metal or non-metal ions is one of the most effective approaches to promote the photocatalytic performance of $\mathrm{ZnO}$. Metal doping can enhance the photocatalytic performance of $\mathrm{ZnO}$ by tuning the band-gap, introducing localized states, and modifying the morphology of $\mathrm{ZnO}$. So far, a number of metal atoms, including, $\mathrm{Al}, \mathrm{Co}, \mathrm{Mn}, \mathrm{Ag}, \mathrm{Fe}, \mathrm{Mg}$, etc. [16] in the form of dopants were introduced into the $\mathrm{ZnO}$ crystal lattice to substitute $\mathrm{Zn}$. An improvement in the doping technology of $\mathrm{ZnO}$ by $\mathrm{Mg}$ [17] has promoted many new applications in electronics and ultraviolet optoelectronic devices. Moreover, $\mathrm{ZnO}$ can be alloyed with high optical band-gap II-VI compounds like magnesium oxide $(\mathrm{MgO})$ to raise its bandgap. The resulting new compound, $\mathrm{Zn}_{1-\mathrm{x}} \mathrm{Mg}_{\mathrm{x}} \mathrm{O}$, has appeared as one of the most studied semiconductors due to its high band-gap. Rouchdi et al reported that many eminent researchers have analyzed the properties of $\mathrm{Mg}$ doped $\mathrm{ZnO}$ thin films, which showed that the structural, optical and electrical properties changed of $\mathrm{ZnO}$ after doping [6].

Thin films are of particular interest for photocatalysis as they are associated with a large surface/volume ratio, thereby limiting the possibility of electron-hole recombinations and the use of raw material. Therefore, good catalytic efficiency with a limited amount of matter can be achieved. In order to fabricate films, there are several methods such as sol-gel spin-/dip-coating [18, 19], spray pyrolysis [20], chemical bath deposition, pulsed laser deposition [21], and sputtering. Costeffectiveness, thickness control, high transparency, versatility to synthesize multicomponent oxide layers of different compositions on various substrates, simplicity, excellent compositional control, homogeneity and lower crystallization temperature are special advantages for the fabrication of materials by the sol-gel process [22]. The sol-gel process allows the synthesis of materials of the same composition in various physical forms and coatings by changing experimental conditions.

In this paper, undoped $\mathrm{ZnO}$ and $\mathrm{Mg}$-doped $\mathrm{ZnO}$ films were successfully prepared via a sol-gel procedure using a dip-coating process. The influence of magnesium addition on structural, morphological, optical properties and photocatalytic performance of $\mathrm{ZnO}$ films are investigated.

\section{Materials and methods}

2.1 Synthesis of $\mathrm{ZnO}$ and $\mathrm{Mg}$-doped $\mathrm{ZnO}$ 
Undoped and Mg-doped $\mathrm{ZnO}(\mathrm{Mg}: 3,5$ and 7 wt. \%) films were synthesized by a sol-gel method using dip-coating technique. The primitive solution was composed of precursor species: zinc acetate di-hydrate $\left(\mathrm{Zn}\left(\mathrm{CH}_{3} \mathrm{COO}\right)_{2} .2 \mathrm{H}_{2} \mathrm{O}\right)$, a dopant source: magnesium acetate tetra-hydrate $\left(\mathrm{Mg}\left(\mathrm{CH}_{3} \mathrm{COO}\right)_{2} .4 \mathrm{H}_{2} \mathrm{O}\right)$, of a solvent: 2-methoxyethanol $\left(\mathrm{C}_{3} \mathrm{H}_{8} \mathrm{O}_{2}\right)$ and of a complexing agent: monoethanolamine (MEA). First, zinc acetate di-hydrate $0.75 \mathrm{~g}$ were dissolved in $30 \mathrm{ml}$ of 2-methoxyethanol with $[\mathrm{Mg}] /[\mathrm{Zn}]$ weight ratios of $0,3,5$ and $7 \mathrm{wt}$. \%. The solution was heated under magnetic stirring at $60^{\circ} \mathrm{C}$ and $0.6 \mathrm{ml}$ monoethanolamine (MEA) was added to accelerate the reaction. The obtained mixture was kept at $60^{\circ} \mathrm{C}$ for $2 \mathrm{~h}$ under constant stirring. Then left free for $24 \mathrm{~h}$ to obtain a clear and homogenous solution. The substrates were cleaned in an ultrasonic bath using acetone, ethanol and distilled water, then dried at room temperature before the deposition of the films. Finally, films were deposited by dip-coating technique onto substrates of glass by the multiple dipping and drying at $350^{\circ} \mathrm{C}$ for $10 \mathrm{~min}$. The coating to drying procedure was repeated ten times for each film. The multilayer films were finally annealed at $500^{\circ} \mathrm{C}$ for $1 \mathrm{~h}$. Figure. 1 show schematic of undoped and $\mathrm{Mg}$-doped $\mathrm{ZnO}$ films synthesis using sol-gel method followed by dip-coating route.

The X-ray diffraction (XRD) data presented in this work were obtained using a PANalytical X'Pert Pro Philips diffractometer (using $\mathrm{Cu} \mathrm{K \alpha}$ radiation source; wavelength $0.15406 \mathrm{~nm}$ ). The morphology of the studied layers was identified by using Atomic Force Microscopy (AFM) using a nano-observer atomic force microscope developed by CS Instruments, and by Environmental Scanning Electronic Microscope type (ESEM) XL 30 FEG Philips. The transmittance was measured using a UV-3101 PC-Shimadzu double-beam spectrophotometer. The Photoluminescence (PL) experiments were performed using Fluorescence Steady-State Spectrofluorometer (Fluorologhoriba) with a 450W (Xe lamp as an excitation source).

2.2 Estimation of photocatalytic potential by the degradation of a dye

The photocatalytic activity of undoped and $\mathrm{Mg}$-doped $\mathrm{ZnO}$ films was predestined by degradation of methylene blue dye (MB) under UV-light irradiation. An aqueous $\mathrm{MB}$ solution $(50 \mathrm{~mL})$ with an initial concentration of $10^{-5} \mathrm{M}$ was placed in a cylindrical glass vessel. Subsequently, undoped and $\mathrm{Mg}$-doped $\mathrm{ZnO}$ films on the side were dipped into the petri dish, which contains the MB solution. Before the irradiation with UV-light source, the equilibrium of adsorption and desorption the 
dark treatment of MB with photocatalyst was operated for $30 \mathrm{~min}$, after that irradiated with light UV (365 nm 15W) at room temperature. The UV-light lamp was located at a distance of $8.10^{-2} \mathrm{~m}$ above the top surface of the dye solution. The samples were taken out every $30 \mathrm{~min}$ from the reactor during irradiation, and the absorbance spectra were recorded using UV-3101 PC-Shimadzu double-beam spectrophotometer. The degradation efficiency of MB can be evaluated employing the following equation [23]

Degradation efficiency $=\left(\frac{C_{0}-C_{t}}{C_{0}}\right) \times 100 \%$

Where $\mathrm{C}_{0}$ is the initial concentration of dye solution, $\mathrm{C}_{\mathrm{t}}$ is the concentration of dye solution after irradiation. The kinetics of the degradation has been demonstrated by Langmuir-Hinshelwood (L-H) model and can be written as [24]

$\mathrm{r}=\frac{\mathrm{dC}}{\mathrm{dt}}=\frac{K C}{1+k K C}$

Where $\mathrm{K}$ is the absorption coefficient of the $\mathrm{MB}, \mathrm{k}$ is the rate constant, $\mathrm{C}$ is the concentration and $\mathrm{r}$ is the mineralization rate. When $\mathrm{C}_{0}$ is very small, $\mathrm{L}-\mathrm{H}$ kinetics can be approached to first-order expression by the attached equations, $k_{\text {app }}$ is the firstorder rate constant.

$\mathrm{r}=\frac{\mathrm{dC}}{\mathrm{dt}}=\mathrm{kKC}=\mathrm{k}_{\mathrm{app}} \mathrm{C}$

Integrating the above equation,

$\mathrm{C}_{\mathrm{t}}=\mathrm{C}_{0} \mathrm{e}^{\mathrm{k}_{\mathrm{app}} \mathrm{t}}$

Or

$\ln \left(\frac{C_{0}}{C_{t}}\right)=k_{a p p} t$ 


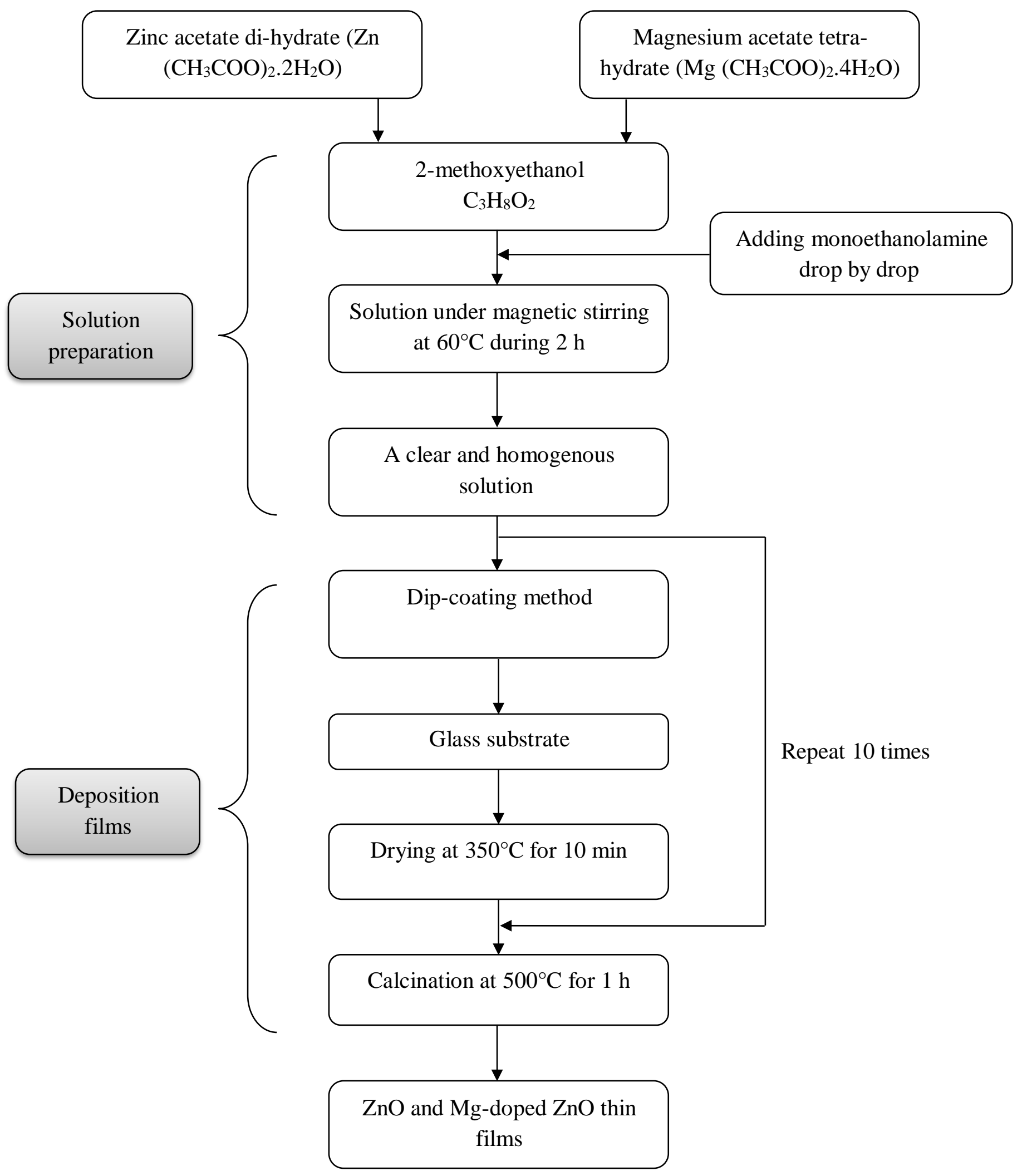

Fig. 1 Synthesis diagram of undoped and $\mathrm{Mg}$-doped $\mathrm{ZnO}$ thin films. 


\section{Results and Discussion}

\subsection{Energy dispersive spectroscopy of X-ray (EDX)}

The elemental analysis of undoped $\mathrm{ZnO}$ and $\mathrm{Mg}$-doped $\mathrm{ZnO}$ thin films was analyzed by EDX. Figure. 2 displays the EDX of $\mathrm{ZnO}$ and $\mathrm{Mg}$-doped $\mathrm{ZnO}$ thin films. EDX spectra exhibit the peaks characteristic of the $\mathrm{O}-\mathrm{K}, \mathrm{Zn}-\mathrm{L}, \mathrm{Mg}-\mathrm{K}$ transitions corresponding to film constituents as well as $\mathrm{Au}-\mathrm{M}$ and $\mathrm{Si}-\mathrm{K}$ transitions corresponding to glass substrate and thin gold deposition to avoid charge accumulation during measurement. The Semi-quantitative analyses from EDX measurement of the prepared films are presented in Table 1. The oxygen content is generally overestimated EDX. Moreover, some of the oxygen signal originates from the glass substrate. To estimate the $\mathrm{Mg}$ content in the film we have considered that it is half of the $\mathrm{Mg} /(\mathrm{Mg}+\mathrm{Zn})$ ratio since the $\mathrm{O} / \mathrm{Mg}$ and $\mathrm{Zn} / \mathrm{O}$ ratios are supposed equal to 1. The estimated $\mathrm{Mg}$ content ranges between 0 for pure $\mathrm{ZnO}$ and 6.4 at. \%. The measurements indicated that $\mathrm{Mg}$ is well incorporation into $\mathrm{ZnO}$ films using our solgel. Considering that only diffraction signal of $\mathrm{ZnO}$ was detected, we can consider that the process has well led to $\mathrm{Mg}$ doping. Even if the presence of secondary amorphous or very fine crystalline phase cannot be discarded, complete incorporation of $\mathrm{Mg}$ into $\mathrm{ZnO}$ is plausible knowing that the solubility limit of $\mathrm{MgO}$ into $\mathrm{ZnO}$ is in the range 5-8 mol \% [25]. In the following the samples will be referred as $\mathrm{ZnO}, 4.9 \%$ Mg-doped $\mathrm{ZnO}, 6 \% \mathrm{Mg}$-doped $\mathrm{ZnO}, 6.4 \% \mathrm{Mg}$-doped $\mathrm{ZnO}$, in order to consider the actual at. \% $\mathrm{Mg}$ incorporated into the films.

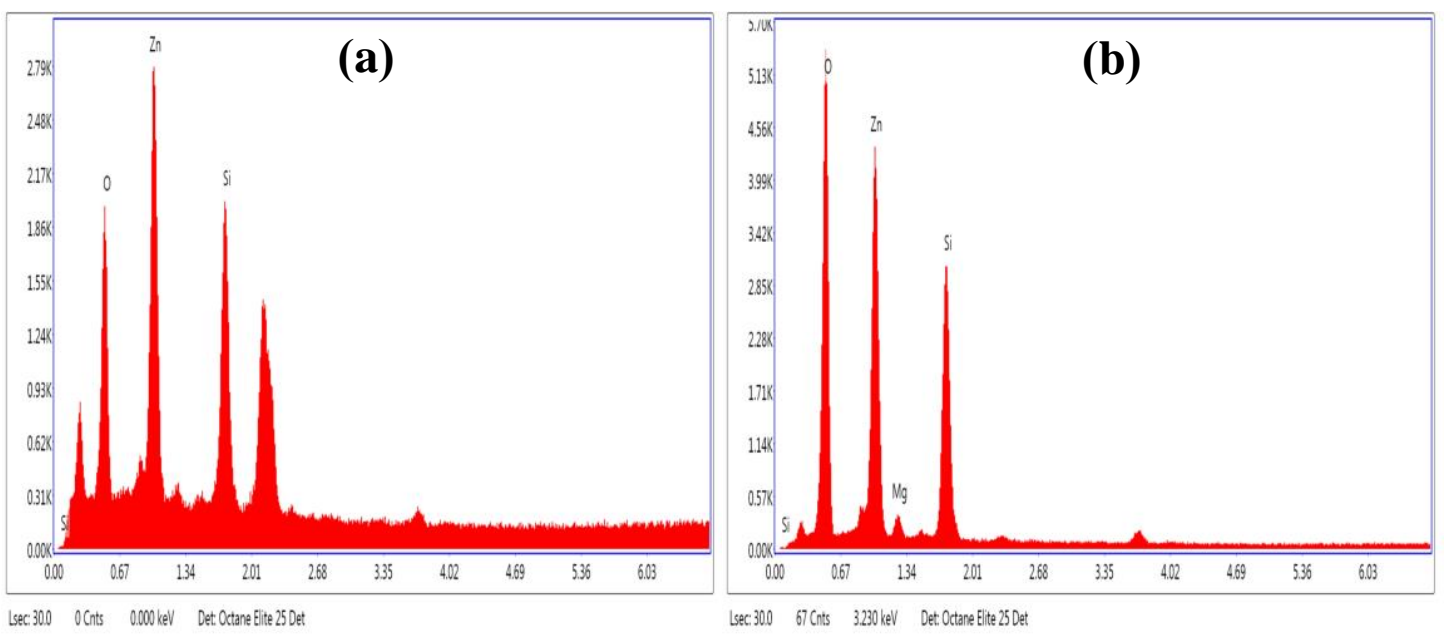



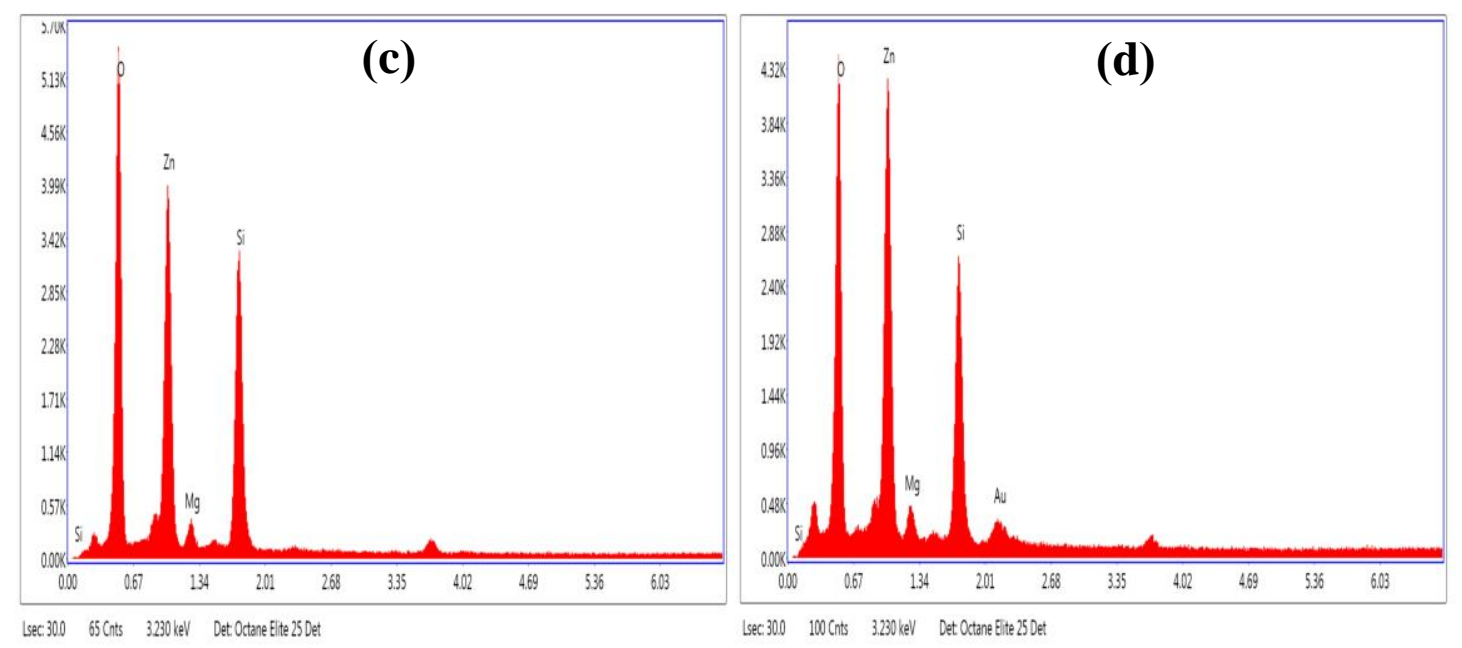

Fig. 2 EDX spectra of (a) undoped $\mathrm{ZnO}$, (b) $\mathrm{Mg}$-doped $\mathrm{ZnO}$ (4.9 at. \%), (c) $\mathrm{Mg}$ doped $\mathrm{ZnO}$ (6 at. \%), and (d) $\mathrm{Mg}$-doped $\mathrm{ZnO}$ (6.4 at. \%) films.

Table 1 Semi-quantitative analysis of EDX measurement of the prepared films

\begin{tabular}{llll}
\hline Composition of ZnO films & Element & Weight (\%) & Atom (\%) \\
\hline Undoped $\mathrm{ZnO}$ & $\mathrm{Zn}$ & 47.41 & 22.84 \\
& $\mathrm{O}$ & 21.47 & 42.25 \\
Mg-doped ZnO 4.9 at. \% & $\mathrm{Si}$ & 31.13 & 34.91 \\
& $\mathrm{Zn}$ & 42.81 & 18.37 \\
& $\mathrm{O}$ & 32.14 & 56.35 \\
& $\mathrm{Mg}$ & 1.74 & 2.01 \\
Mg-doped ZnO 6.0 at. \% & $\mathrm{Si}$ & 23.30 & 23.27 \\
& $\mathrm{Zn}$ & 40.12 & 16.83 \\
& $\mathrm{O}$ & 33.11 & 56.73 \\
& $\mathrm{Mg}$ & 2.03 & 2.29 \\
& $\mathrm{Si}$ & 24.74 & 24.15 \\
Mg-doped ZnO 6.4 at. \% & $\mathrm{Zn}$ & 45.63 & 20.85 \\
& $\mathrm{O}$ & 28.74 & 53.65 \\
& $\mathrm{Mg}$ & 2.50 & 3.08 \\
& $\mathrm{Si}$ & 20.75 & 22.06 \\
& $\mathrm{Au}$ & 2.38 & 0.36 \\
\hline
\end{tabular}

3.2 X-ray diffraction (XRD) analysis

Figure. 3 shows the XRD patterns of $\mathrm{ZnO}$ and $\mathrm{Mg}$-doped $\mathrm{ZnO}$ films after the thermal treatment at $500^{\circ} \mathrm{C}$ for $1 \mathrm{~h}$. All diffraction peaks (100), (002) and (101) were 
indexed with the hexagonal wurtzite crystal structure of ZnO (JCPDS card no. 361451). From the XRD patterns, it is obvious that no peak of crystalline $\mathrm{MgO}$ or any other impurity phases could be detected. This suggests $\mathrm{Mg}$ is efficiently incorporated into the $\mathrm{ZnO}$ lattice without phase segregation occurs. The relative recorded diffracted intensities of the different peaks compared with the theoretical ones in a random configuration (JCPDS card no. 36-1451), indicate that the films are preferentiallyoriented along the c-axis of the wurtzite structure as the signal for (002) peak dominates the diffractograms. This is all the more pronounced as the $\mathrm{Mg}$ is increases: the relative intensity ratio between (002) peak and other ones increases with the increase of $\mathrm{Mg}$ content. Whereas the width of the (002) intense peak decreases with the $\mathrm{Mg}$ concentration, indicating the average size of crystallites increases. We note that the (101) plane has a higher intensity than (100). Rouchdi et al reported that the surface energy of (101) plane is the lowest that the surface energy of (100) plane of $\mathrm{ZnO}$ crystal [6].

Additionally, the crystallinity of the $\mathrm{ZnO}$ phase improved with the addition of $\mathrm{Mg}$ into $\mathrm{ZnO}$ lattice as the overall diffracted intensity increases [26]. Notably, with increasing $\mathrm{Mg}$ dopant concentration, the position of the intense peaks (002) slightly shifted toward lower diffraction angles. Figure. 4 shows the X-ray diffraction shifted in diffraction peaks (002) with Mg doping. This shift is due to the incorporation of $\mathrm{Mg}$ into the $\mathrm{ZnO}$, better highlights this shift. It corresponds to an expansion of the $\mathrm{c}(\AA)$ lattice parameter and the same is observed for the $\mathrm{a}(\AA)$ axis parameter by considering the shift in the position of the (100) peak [27]. Yet, the c-axis parameter of the undoped film is lower than that of bulk $\mathrm{ZnO}$, suggesting pure $\mathrm{ZnO}$ film is in a tensile state before doping. Introduction of $\mathrm{Mg}$ into $\mathrm{ZnO}$ appears to relax this situation as the c-axis approaches to the bulk value upon $\mathrm{Mg}$ incorporation. 


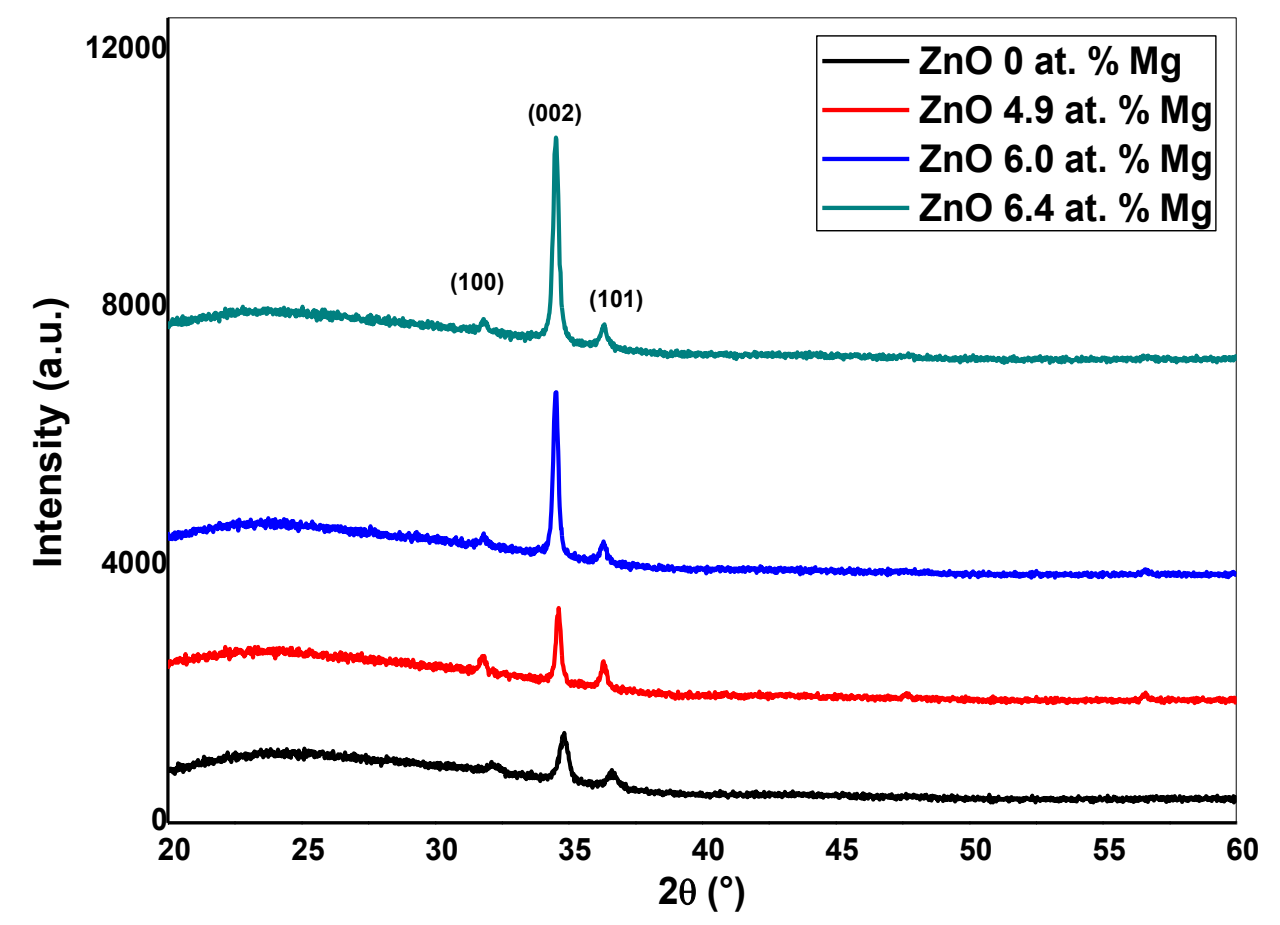

Fig. 3 XRD patterns of undoped and Mg-doped $\mathrm{ZnO}$ (Mg: 4.9, 6 and 6.4 at. \%) films after the thermal treatment at $500^{\circ} \mathrm{C}$ for $1 \mathrm{~h}$.

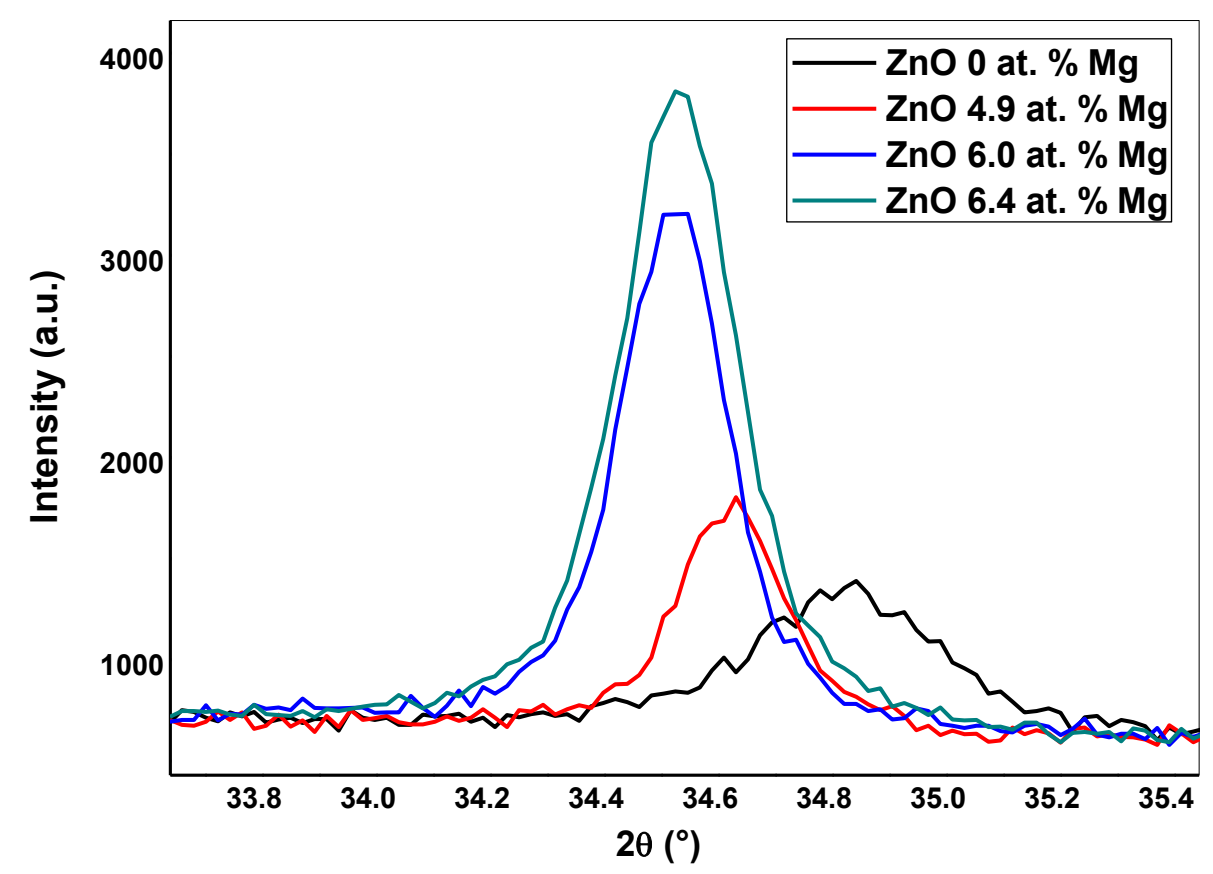

Fig. 4 XRD shifted in the intense diffraction peaks (002) with Mg dopant. 
The crystallite size $\mathrm{D}(\mathrm{nm})$ of undoped and $\mathrm{Mg}$-doped $\mathrm{ZnO}$ films were determined using the Debye-Scherrer relation [28, 29]

$\mathrm{D}=\frac{\mathrm{K} \lambda}{\beta \cos \theta}$

Where $\mathrm{K}$ is the Scherrer constant value equals to $0.9, \lambda$ is the wavelength $(0.154 \mathrm{~nm})$, $\beta$ is the full width at half-maximum (FWHM) intensity and $\theta$ is the Bragg angle.

The residual in-plane stress $\sigma(\mathrm{GPa})$ of films was calculated using the following relations [30]

$\sigma=\left[\mathrm{c}_{13}-\frac{\left(\mathrm{C}_{11}+\mathrm{C}_{12}\right) \mathrm{C}_{33}}{2 \mathrm{C}_{13}}\right] \mathrm{e}_{\mathrm{zz}}$

$\mathrm{e}_{\mathrm{zz}}=\frac{\mathrm{c}-\mathrm{c}_{0}}{\mathrm{c}_{0}}$

Where $\mathrm{c}_{0}$ is the cell parameter of the bulk (taken at $0.520 \mathrm{~nm}$ ), $\mathrm{c}$ is the experimental $\mathrm{c}$ axis parameters, $\mathrm{C}_{\mathrm{ij}}$ the elastic stiffness constants of $\mathrm{ZnO}\left(\mathrm{C}_{11}=209.7 \mathrm{GPa}, \mathrm{C}_{12}=121.1\right.$ $\left.\mathrm{GPa}, \mathrm{C}_{13}=105.1 \mathrm{GPa}, \mathrm{C}_{33}=210.9 \mathrm{GPa}\right)$.

The dislocation density $\delta$ (lines $/ \mathrm{nm}^{2}$ ) was calculated using WilliamsonSmallman formula [31]

$\delta=\frac{1}{\mathrm{D}^{2}}$

The results of the average crystallite size, dislocation density, the stress and the cell parameters were displayed in Table 2. It was noted that in case 4.9 at. \% the average crystallite size increases whereas the dislocation density and stress decrease (see table 2), then when the $\mathrm{Mg}$ concentration increases up to 6 at. \% there is a slight decrease in crystallite size and dislocation density while the trends of the stress continue to decrease, this behavior due to nucleation, growth and activation energy phenomena of the thin films and the substitute of $\mathrm{Zn}^{+2}$ by $\mathrm{Mg}^{+2}$. Furthermore, in the case of 6.9 at. $\%$ the crystallite size reduces significantly whereas the dislocation and the stress increases, this may be attributed to the trend toward the formation of the secondary phase of $\mathrm{MgO}$, due to $\mathrm{Mg}^{2+}$ which could leave the $\mathrm{ZnO}$ lattice, and work to return to a tensile state before doping addition.

Table 2 Structural parameters obtained from XRD analysis and High score plus (data were taken from the intense (002) peak) 


\begin{tabular}{|c|c|c|c|c|c|c|c|}
\hline Samples & $\theta\left(^{\circ}\right)$ & $\beta\left(^{\circ}\right)$ & $\mathrm{D}(\mathrm{nm})$ & $\begin{array}{l}\delta * 10^{-4} \\
\left(\text { lines } / \mathrm{nm}^{2} \text { ) }\right.\end{array}$ & $\sigma(\mathrm{GPa})$ & $\mathrm{a}(\AA)$ & $\mathrm{c}(\AA)$ \\
\hline $\begin{array}{l}\text { Undoped } \\
\mathrm{ZnO}\end{array}$ & 34.79 & 0.36 & 24 & 17.36 & 2.17 & 3.21 & 5.15 \\
\hline $\begin{array}{l}4.9 \text { at. } \% \\
\mathrm{Mg} \text {-doped } \\
\mathrm{ZnO}\end{array}$ & 34.49 & 0.18 & 51 & 3.84 & 0.74 & 3.25 & 5.18 \\
\hline $\begin{array}{l}6 \text { at. } \% \\
\mathrm{Mg} \text {-doped } \\
\mathrm{ZnO}\end{array}$ & 34.49 & 0.19 & 50 & 4.00 & 0.04 & 3.24 & 5.20 \\
\hline $\begin{array}{l}6.4 \text { at. } \% \\
\text { Mg-doped } \\
\mathrm{ZnO}\end{array}$ & 34.50 & 0.22 & 42 & 5.66 & 0.08 & 3.25 & 5.20 \\
\hline
\end{tabular}

3.3 Atomic force microscopy (AFM) analysis

AFM is a useful technique to reveal the quality of the surface morphology and to estimate the lateral grain size and surface roughness. The two (2D) and three (3D) dimensional AFM images of undoped and $\mathrm{Mg}$-doped $\mathrm{ZnO}$ films are shown in Figure. 5. The root mean square roughness (RMS) was deduced from these images and values are given in Table 3. All films present a homogeneous structure with rounded shape grains, an increase and growth in grain width with Mg concentration. The RMS is found to increase with the $\mathrm{Mg}$ content; it changes from $4.46 \mathrm{~nm}$ to $12.30 \mathrm{~nm}$ for $\mathrm{ZnO}$ and 6.4 at. \% Mg-doped $\mathrm{ZnO}$, respectively, means that $\mathrm{Mg}$-doped $\mathrm{ZnO}$ layers have a rougher surface than pure $\mathrm{ZnO}$. This behavior can be related to ease grain growth upon $\mathrm{Mg}$ addition. This higher surface roughness and related larger developed surface area may be an advantage for photocatalysis, dye-sensitized solar cells (DSSCs), and gas sensing. The thickness (d) was measured by using a profilometer instrument; the thickness (d) is shrinking while raising the $\mathrm{Mg}$ content up to 6 at. $\%$ and then increasing slightly for 6.4 at. $\% \mathrm{Mg}$ as represented in Table 3.

Additionally, AFM images also can be used to evaluate the lateral grain size of the prepared samples, the films composed of nano-sized grains with wider grains for $\mathrm{Mg}$-doped $\mathrm{ZnO}$ than undoped $\mathrm{ZnO}$; the $\mathrm{Mg}$-doped $\mathrm{ZnO}$ grain sizes were taken values stretch between $40-50 \mathrm{~nm}$ whereas undoped $\mathrm{ZnO}$ stretch $20 \mathrm{~nm}$. ImageJ software was 
used to acquire the estimated values of grain sizes, these results are in agreement with those gained from XRD.
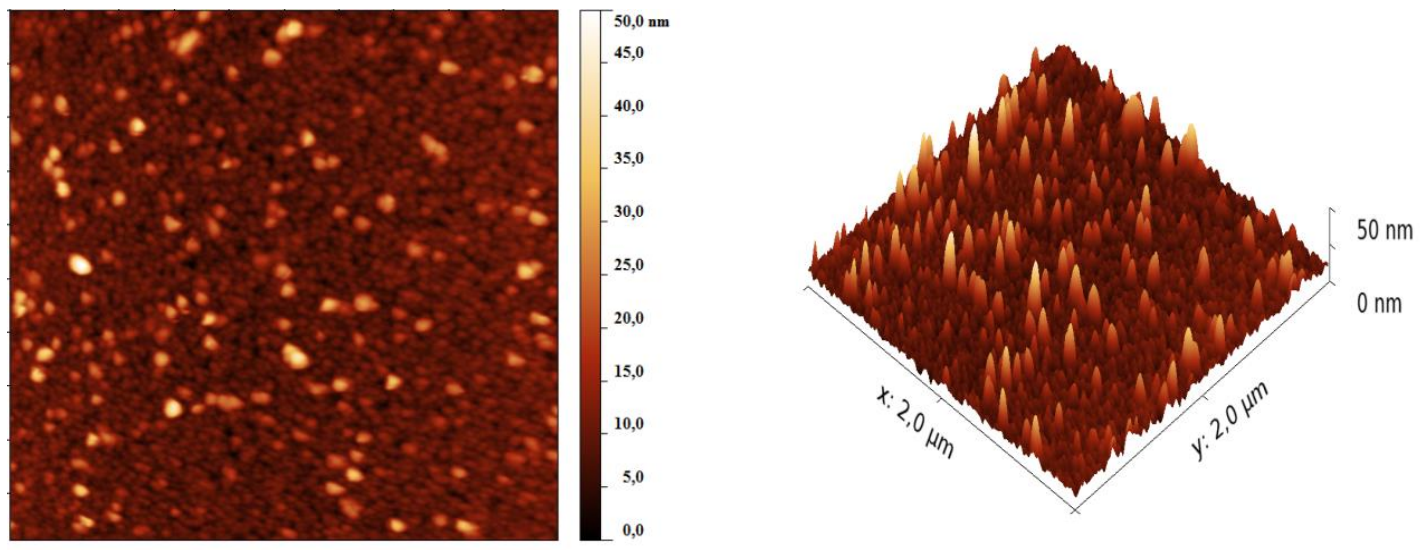

(a) $\mathrm{ZnO} 0$ at. $\% \mathrm{Mg}$
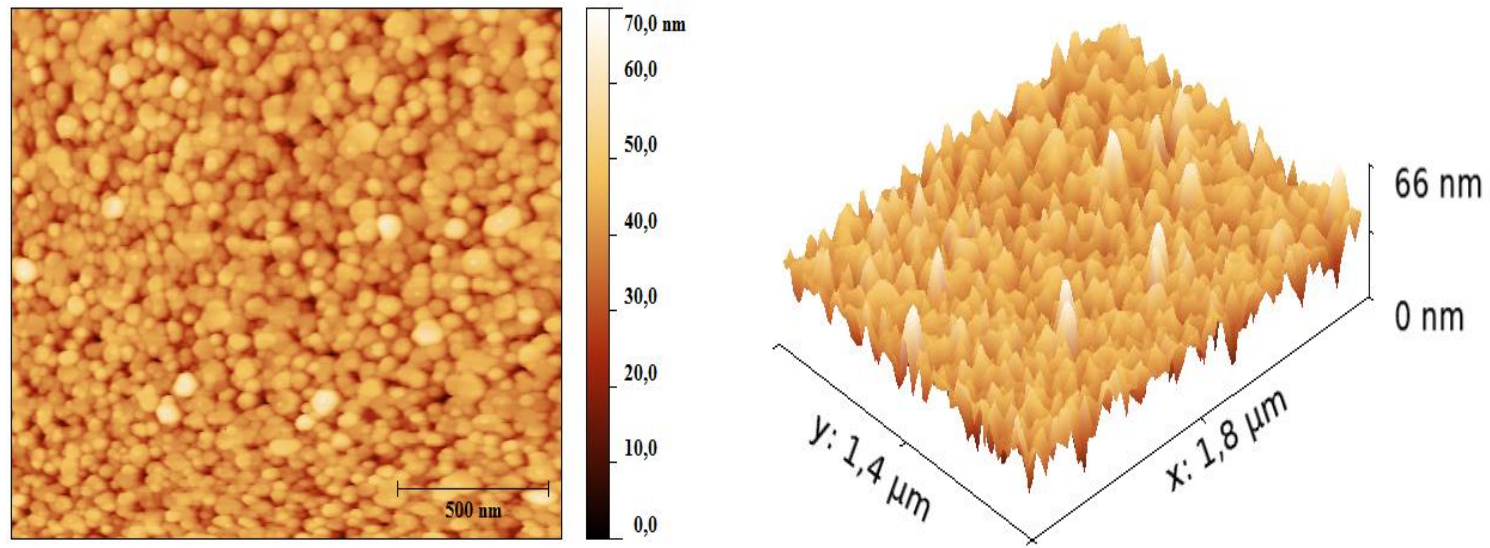

(b) $\mathrm{ZnO} 4.9$ at. $\% \mathrm{Mg}$
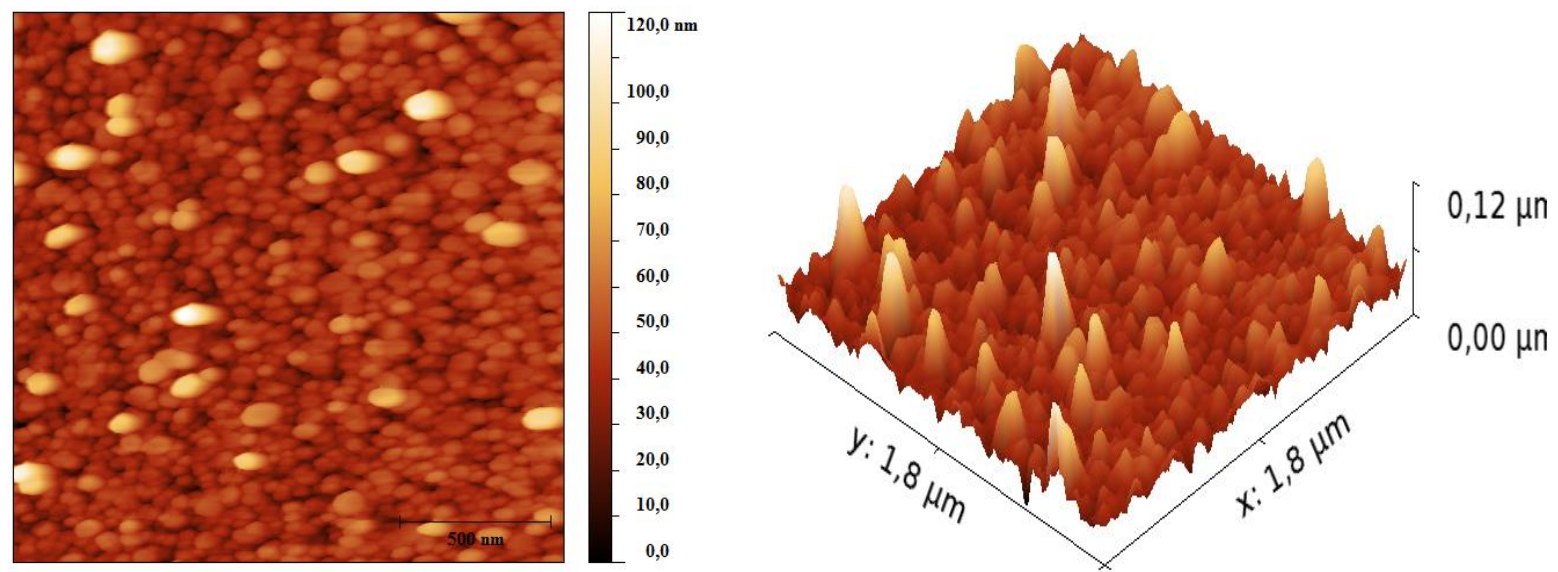

(c) $\mathrm{ZnO} 6$ at. $\% \mathrm{Mg}$ 

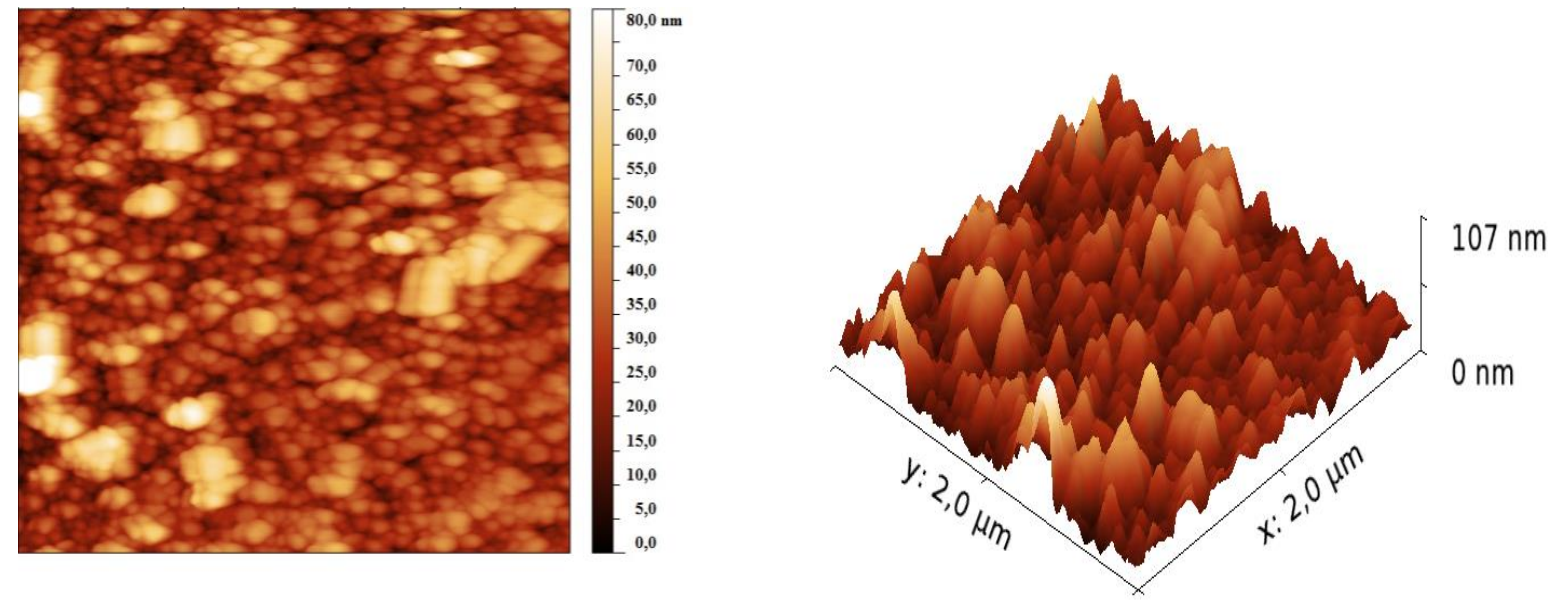

(d) $\mathrm{ZnO} 6.4$ at. $\% \mathrm{Mg}$

Fig. 5 2D and 3D images of AFM of undoped and Mg-doped $\mathrm{ZnO}$ (Mg: 4.9, 6 and 6.4 at. \%) films.

Table 3 Variation of thickness (d), root mean square roughness (RMS) and Ra with $\mathrm{Mg}$ content.

\begin{tabular}{lllll}
\hline Samples & $\begin{array}{l}\text { Undoped } \\
\mathrm{ZnO}\end{array}$ & $\begin{array}{l}\text { Mg-doped ZnO 4.9 } \\
\text { at. \% }\end{array}$ & $\begin{array}{l}\text { Mg-doped ZnO 6 } \\
\text { at. \% }\end{array}$ & $\begin{array}{l}\text { Mg-doped ZnO 6.4 } \\
\text { at. \% }\end{array}$ \\
\hline $\mathrm{d}(\mathrm{nm})$ & 331 & 161 & 134 & 199 \\
$\mathrm{RMS}(\mathrm{nm})$ & 4.46 & 6.48 & 12.20 & 12.30 \\
$\mathrm{Ra}(\mathrm{nm})$ & 2.87 & 5.00 & 8.40 & 9.40 \\
\hline
\end{tabular}

\subsection{Environmental Scanning Electron Microscopy (ESEM)}

The morphology of the films was studied by the ESEM. The images of undoped and $\mathrm{Mg}$-doped $\mathrm{ZnO}$ films and cross section obtained by sol-gel route are illustrated in Figure. 6. These images indicate that the films are exempt of cracks or voids. The surface of all the layers exhibits wrinkles and very small crystallites; these wrinkles are linked with each other and with the addition of magnesium to the layers, the wrinkles are shrinking and their density increases. The presence of these wrinkles developed the surface area of the film larger than the projected surface area, which should be beneficial for catalysis. 

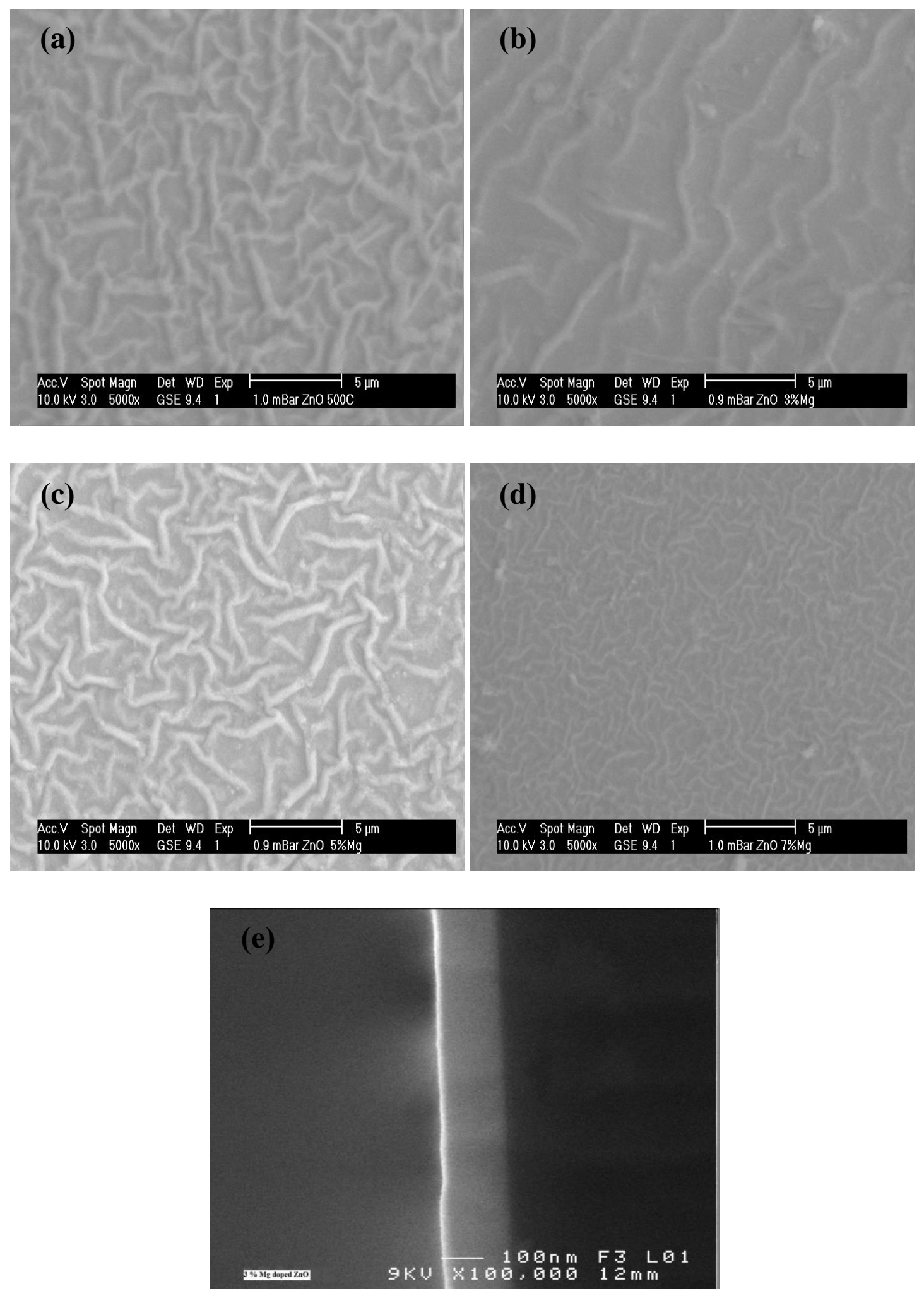

Fig. 6 ESEM images of: (a) undoped $\mathrm{ZnO}$, (b) 4.9 at. \% $\mathrm{Mg}-\mathrm{ZnO}$, (c) 6 at. \% $\mathrm{Mg}$ $\mathrm{ZnO}$ and (d) 6.4 at. \% Mg- $\mathrm{ZnO}$, (e) Cross section of thin films. 


\subsection{UV- Visible analysis}

The optical transmittance of undoped and $\mathrm{Mg}$-doped $\mathrm{ZnO}$ films were recorded in 300-800 $\mathrm{nm}$ wave-length range and reported in Figure. 7. It was noticed that all films exhibited a high level average transparence in the visible range (70-80\%) and showed a strong absorption in the UV region; the transmittances edge slightly shifted towards lower wave-length is spotted for the transmittance edge of $\mathrm{Mg}$-doped $\mathrm{ZnO}$ films. This is due to an increase in the band-gap energy of $\mathrm{Mg}$-doped $\mathrm{ZnO}$.

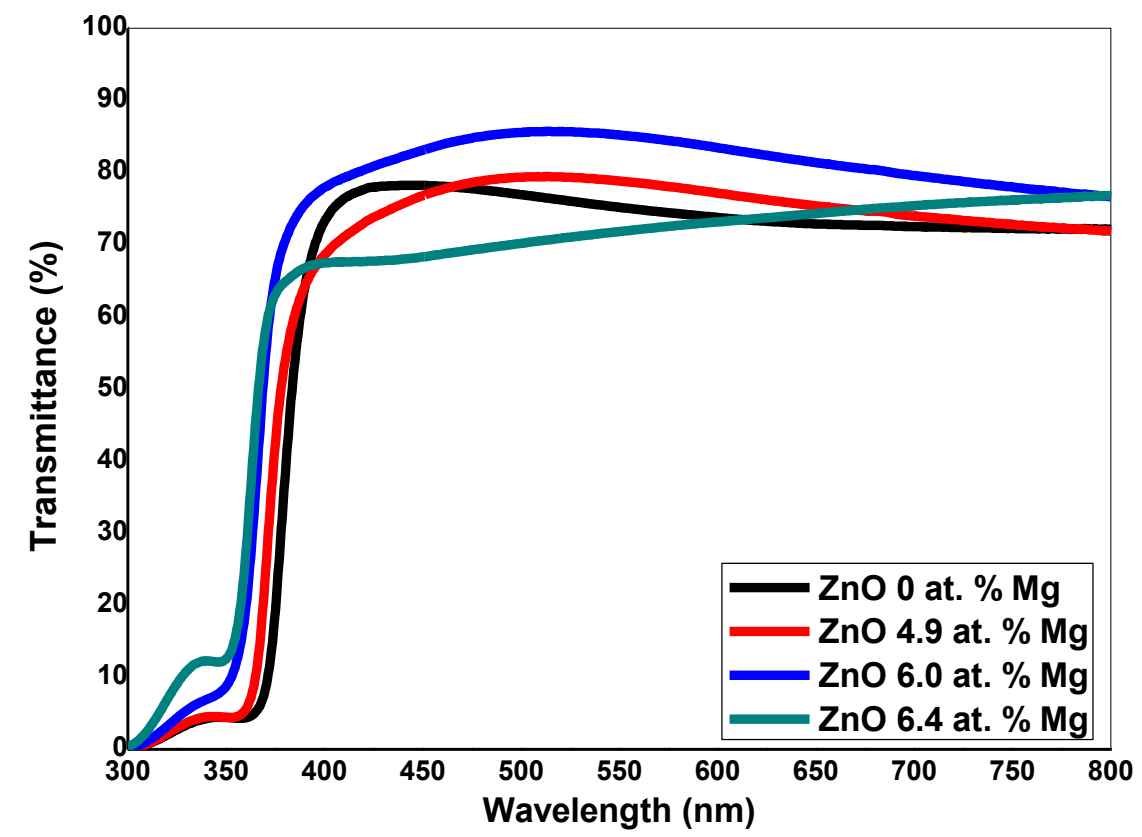

Fig. 7 Transmittance spectra of undoped and Mg-doped $\mathrm{ZnO}$ (Mg: 4.9, 6 and 6.4 at. $\%)$ films.

The optical band-gap was determined from the transmittance spectra using the Tauc formula [32]

$(\alpha h v)^{2}=B\left(h v-E_{g}\right)$

Where $\alpha$ is the absorption coefficient, B is the constant, h is the Planck's constant, $v$ is the photon frequency, and Eg is the optical band-gap. When $(\alpha h v)^{2}=0, E g=h v$, an extrapolation of the linear region of the plot of $(\alpha h v)^{2}$ versus photon energy $(h v)$ on the $\mathrm{x}$-axis gives the value of the optical band gap Eg, Figure. 8 shows the extrapolation of the curves $(\alpha h v)^{2}$ as a function of the photon energy hv. The band-gap values obtained from undoped and $\mathrm{Mg}$-doped $\mathrm{ZnO}(\mathrm{Mg}: 4.9,6$ and 6.4 at. \%) films were presented in Table 4 . 


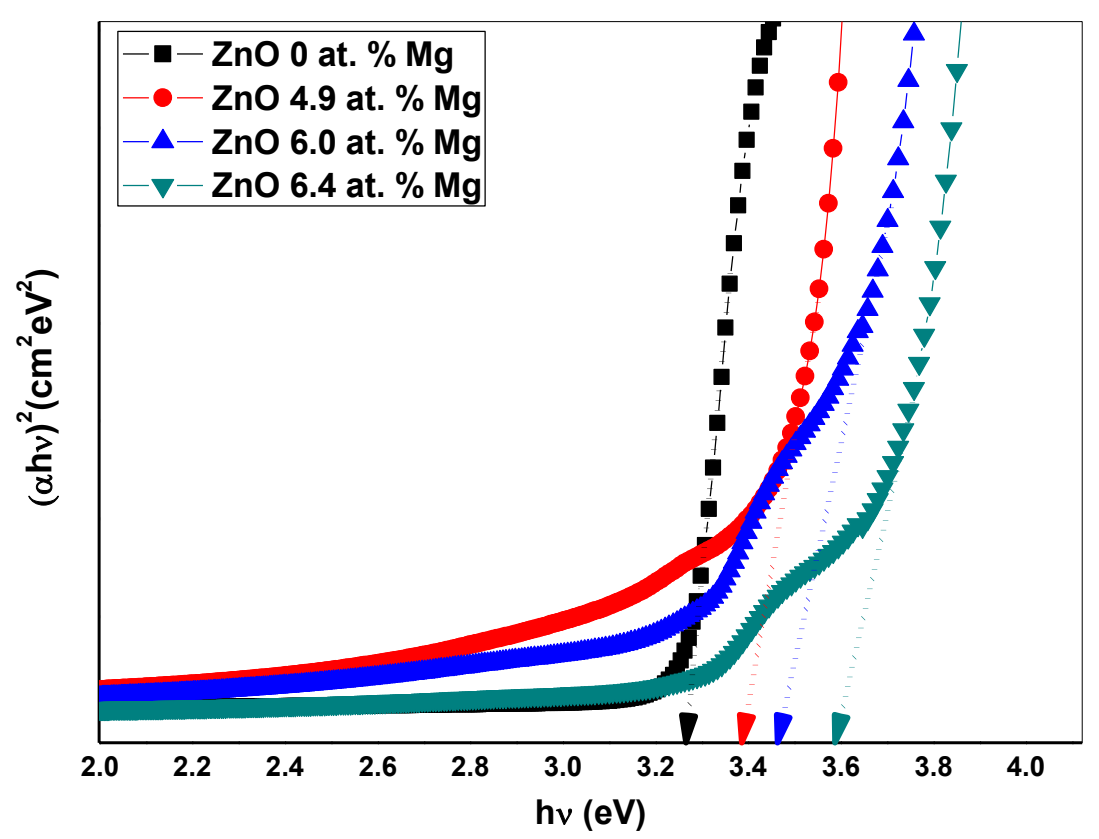

Fig. 8 The extrapolation of the curves $(\alpha h v)^{2}$ as a function of photon energy hv of undoped and $\mathrm{Mg}$-doped $\mathrm{ZnO}(\mathrm{Mg}: 4.9,6$ and 6.4 at. \%) films.

It was observed that the $\mathrm{Mg}$ dopant increases the band-gap and this is all the more pronounced as the $\mathrm{Mg}$ is increased. This monotonous increase of the band-gap tends to confirm that $\mathrm{Mg}$ was well incorporated into the $\mathrm{ZnO}$ crystal lattice. The highest band-gap of about $3.59 \mathrm{eV}$ was acquired for 6.4 at. \% $\mathrm{Mg}$-doped $\mathrm{ZnO}$ as presented in Table 4. The increase in band-gap can be linked to the fact that new defects are inserted after $\mathrm{Mg}^{2+}$ substitute for $\mathrm{Zn}^{2+}$, owing to the electronegativity and ionic radius differences between $\mathrm{Mg}$ and $\mathrm{Zn}$, there are more electrons shared by $\mathrm{Mg}$ dopant related to the lower electron affinity of $\mathrm{MgO}$ compared to $\mathrm{ZnO}$. This causes a shift of the Fermi level inside the conduction band in the case of $\mathrm{Mg}$-doped $\mathrm{ZnO}$, or because of the wide band-gap of $\mathrm{MgO}$ comparing to $\mathrm{ZnO}[6,16]$. These results make our deposited films candidates for use in optoelectronics, photovoltaics and multiple optical applications although this is not the focus of the present study.

Table 4 Band-gap of undoped and $\mathrm{Mg}$-doped $\mathrm{ZnO}$ films obtained by UV-Visible spectroscopy. 


\begin{tabular}{ll}
\hline Samples & Band-gap (eV) \\
\hline Undoped ZnO & 3.28 \\
$\mathrm{Mg}-\mathrm{ZnO}(4.9$ at. \%) & 3.39 \\
$\mathrm{Mg}-\mathrm{ZnO}$ (6 at. \%) & 3.48 \\
$\mathrm{Mg}-\mathrm{ZnO}(6.4$ at. \%) & 3.59 \\
\hline
\end{tabular}

3.6 Photoluminescence (PL) analysis

The PL measurements of undoped and $\mathrm{Mg}$-doped $\mathrm{ZnO}$ films were carried out at room temperature (excitation wave-length $325 \mathrm{~nm}$ ) in the range of 300-800 $\mathrm{nm}$. The photoluminescence spectra of undoped and $\mathrm{Mg}$-doped $\mathrm{ZnO}$ films were shown in Figure. 9. Emission peaks of undoped and $\mathrm{Mg}$-doped $\mathrm{ZnO}$ exhibit a near band edge emission (NBE) (UV PL) and violet- yellow- red emission (visible PL) (Figure. 9). To define the center of every luminescence band, the signal has been deconvoluted with Gaussian curves. The deconvoluted photoluminescence of undoped and $\mathrm{Mg}$ doped $\mathrm{ZnO}$ (Mg: 4.9, 6 and 6.4 at. \%) films can be observed in Figure. 10.

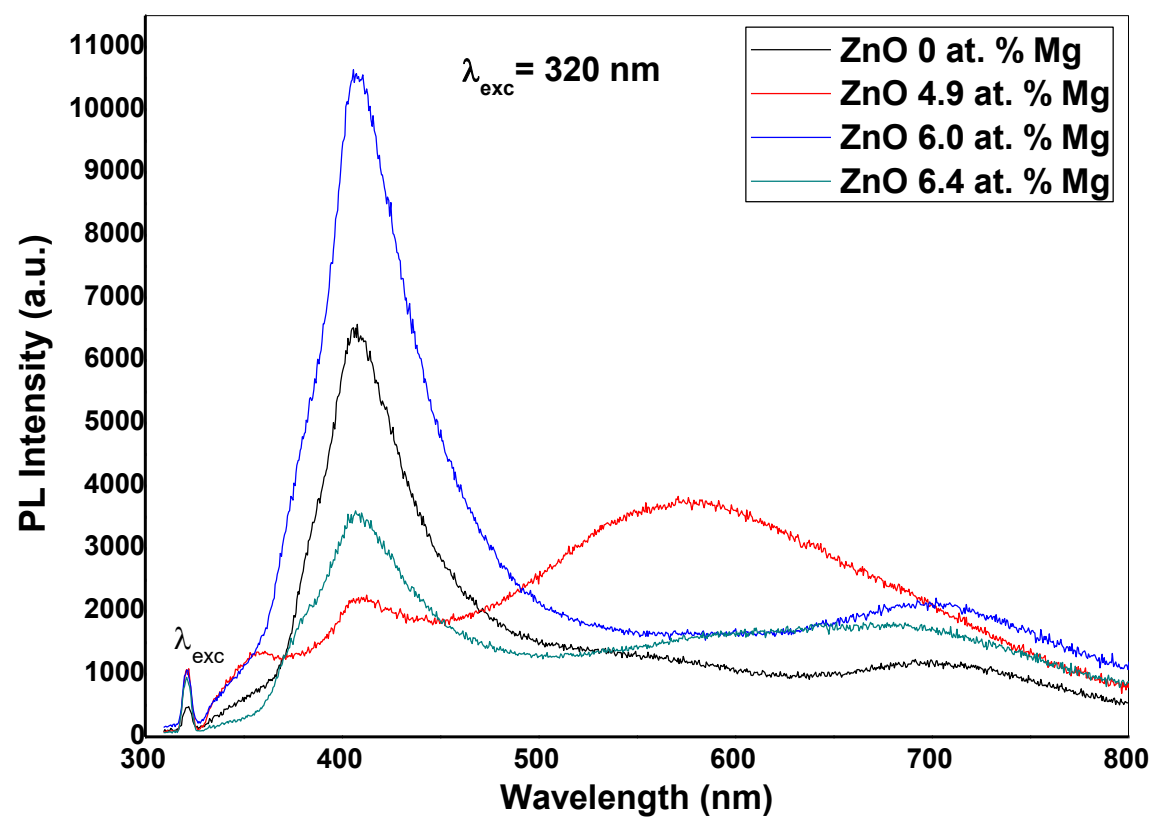

Fig. 9 Photoluminescence spectra of undoped and Mg-doped $\mathrm{ZnO}(\mathrm{Mg}: 4.9,6$ and 6.4 at. \%) films.

The emission spectra show two main emissions. One is the near band edge emission (NBE) at the boundary between ultraviolet and visible located at $364 \mathrm{~nm}$ 
(3.40 eV), $377 \mathrm{~nm}(3.28 \mathrm{eV})$ and $382 \mathrm{~nm}(3.24 \mathrm{eV})$, depending on the samples, originated from free-exciton recombination in the UV region. Its position blue-shifts from $382 \mathrm{~nm}(3.24 \mathrm{eV})$ to $364 \mathrm{~nm}(3.40 \mathrm{eV})$ with Magnesium addition, all the more as the $\mathrm{Mg}$ dopant are increased. This is in line with the results gained from spectrophotometry. Hence, the band-gap of $\mathrm{ZnO}$ is controlled by the $\mathrm{Mg}$ content. This may be due to the impurities, defects and crystal quality [33].

The second one is the broad visible emission located at $405 \mathrm{~nm}(3.06 \mathrm{eV}), 407$ nm (3.03 eV), $408 \mathrm{~nm}(3.03 \mathrm{eV}), 416 \mathrm{~nm}(2.98 \mathrm{eV}), 422 \mathrm{~nm}(2.93 \mathrm{eV}), 446 \mathrm{~nm}(2.78$ $\mathrm{eV}), 478 \mathrm{~nm}(2.59 \mathrm{eV}), 584 \mathrm{~nm}(2.12 \mathrm{eV}), 631 \mathrm{~nm}(1.96 \mathrm{eV}), 690 \mathrm{~nm}(1.79 \mathrm{eV}), 700$ $\mathrm{nm}(1.77 \mathrm{eV})$ and $712 \mathrm{~nm}(1.74 \mathrm{eV})$, depending on sample. It is known to be composed of various contributions usually ascribed to deep level defects in the visible range. Different types of impurities and structural defects such as zinc interstitials (Zni), zinc vacancies (VZn), oxygen interstitials (Oi), antisite oxygen (OZn), zinc antisite $(\mathrm{ZnO})$ and donor-acceptor pair (DAP) have been proposed as the origins of this deep-level emission (DLE) broad band [34, 35, 36].

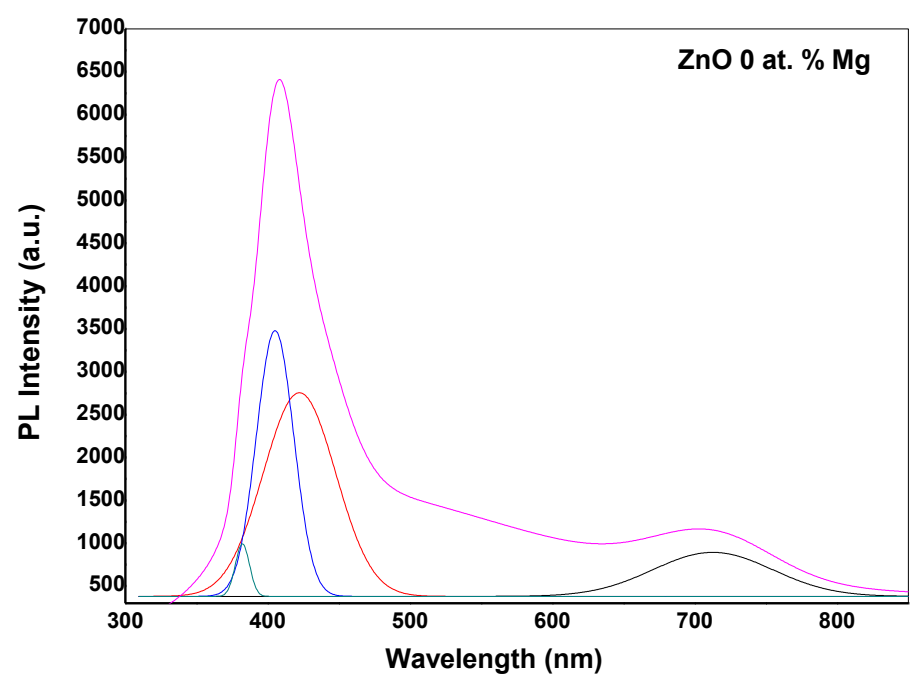



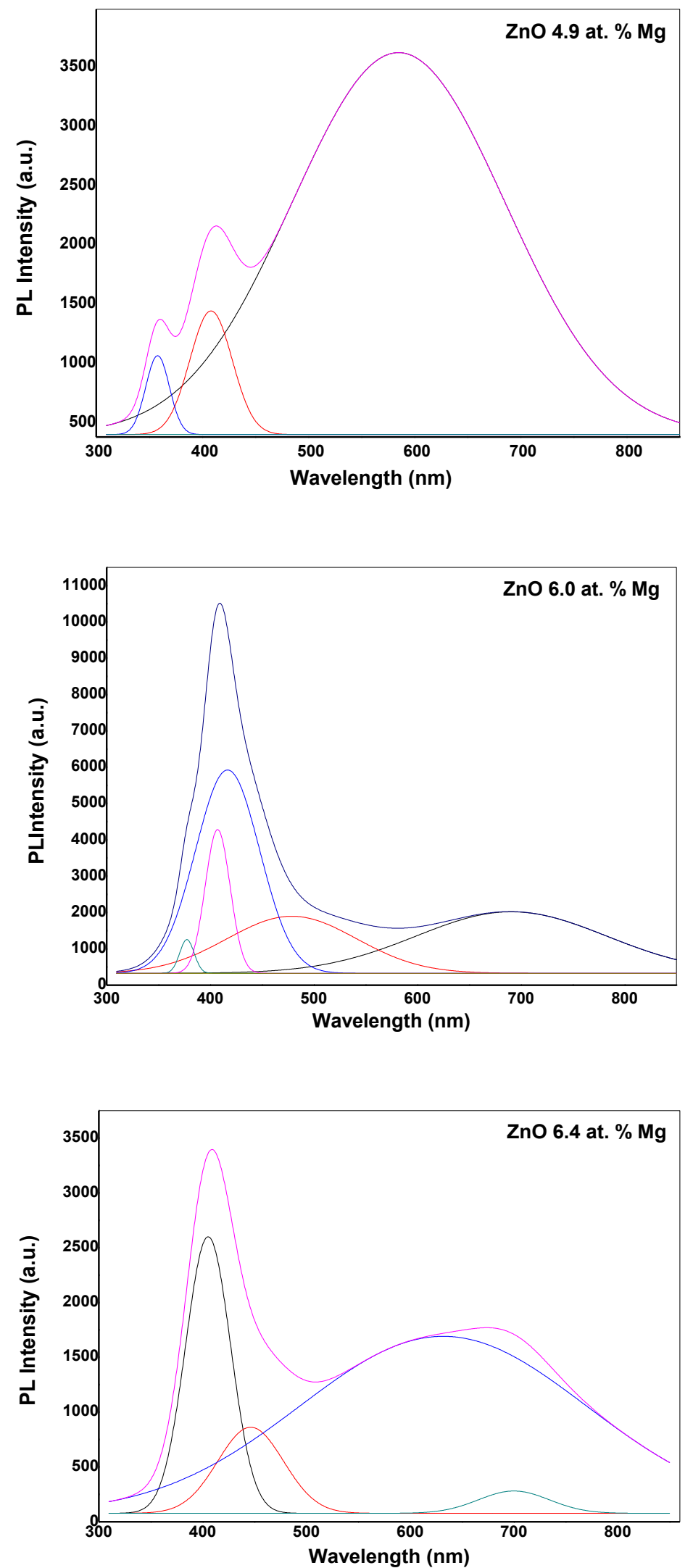

Fig. 10 Deconvolution photoluminescence spectra of undoped and $\mathrm{Mg}$-doped $\mathrm{ZnO}$ (Mg: 4.9, 6 and 6.4 at. \%) films. 


\subsection{Photocatalytic activity}

Photocatalytic degradation of the synthesized undoped and $\mathrm{Mg}$-doped $\mathrm{ZnO}$ films was carried out using the photo-degradation process of organic MB dye under UV-light $(365 \mathrm{~nm})$, the photolysis of MB and catalyst the dark adsorption was done before realizing the photocatalytic. Figure. 11 displays the absorbance spectra of MB as a function of irradiation time of undoped and $\mathrm{Mg}$-doped $\mathrm{ZnO}$ films. The curve of MB contains two absorption peaks in the domain of 400 to $800 \mathrm{~nm}$; the absorption peak at $664 \mathrm{~nm}$ was selected as the reference to examine the degradation abilities of undoped and $\mathrm{Mg}$-doped $\mathrm{ZnO}$. The intensity of main absorption peaks decreases gradually with light exposure as a function of time using undoped and $\mathrm{Mg}$-doped $\mathrm{ZnO}$ films. After $330 \mathrm{~min}, \mathrm{Mg}$-doped $\mathrm{ZnO}$ (Mg: 6 and 6.4 at. \%) enables us to completely degrade MB in water.
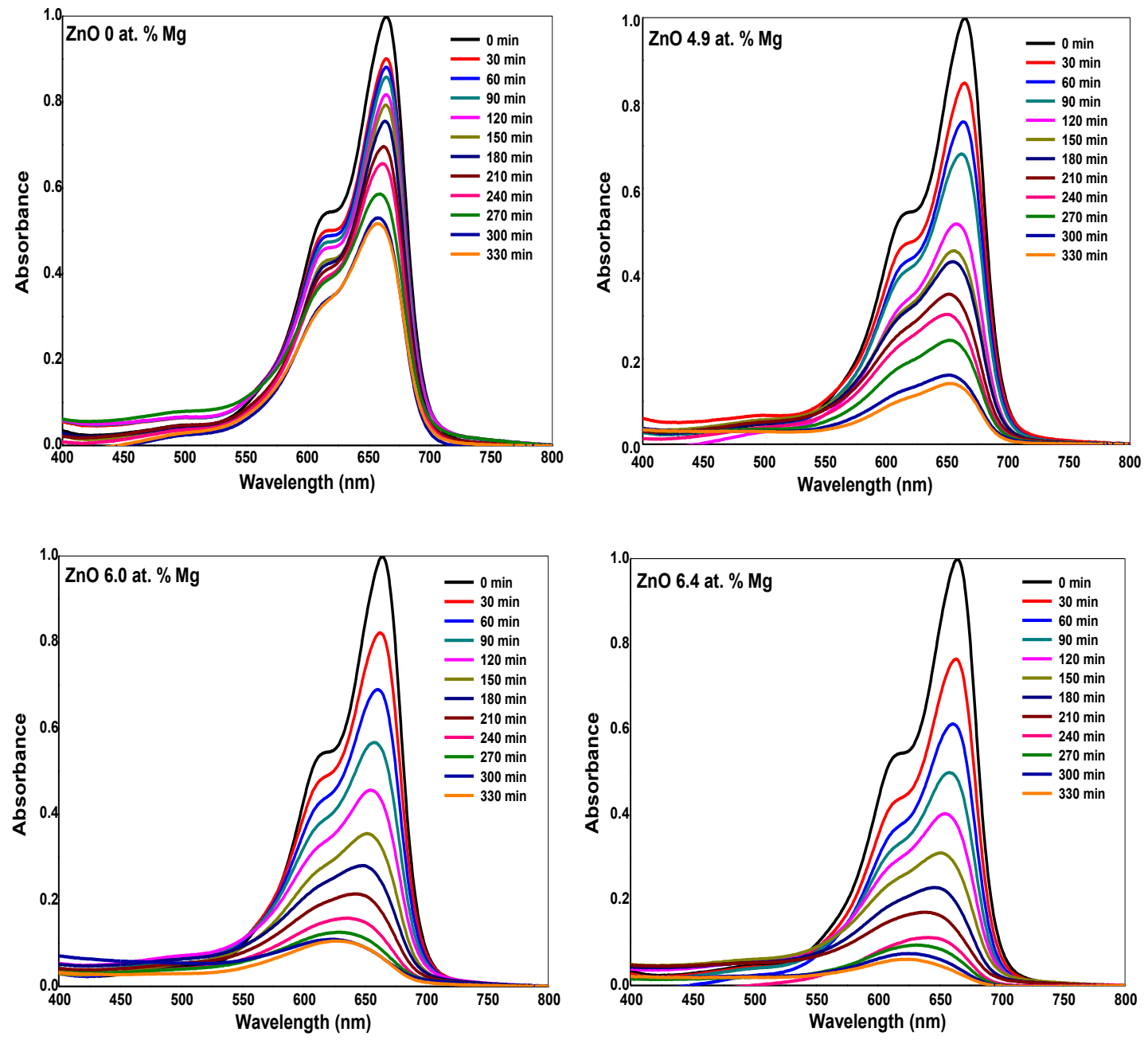

Fig. 11 Absorbance spectra of $\mathrm{MB}$ versus irradiation time of undoped and $\mathrm{Mg}$-doped $\mathrm{ZnO}$ (Mg: 4.9, 6 and 6.4 at. \%) films as a function of wavelength. 
Figure. 12 shows the concentration ratio $\left(\mathrm{C} / \mathrm{C}_{0}\right)$ of $\mathrm{MB}$ dye versus the time of undoped and $\mathrm{Mg}$-doped $\mathrm{ZnO}$ films. It is clear that there is no degradation of $\mathrm{MB}$ in the absence of undoped and $\mathrm{Mg}$-doped $\mathrm{ZnO}$ under irradiation. Obviously, the photocatalytic performance of $\mathrm{Mg}$-doped $\mathrm{ZnO}$ is greatly improved and the 6.4 at. \% $\mathrm{Mg}$-doped $\mathrm{ZnO}$ has the best degradation efficiency and exhibited faster degradation. The kinetics of the reaction was estimated by plotting the natural logarithm of the concentration ratios of MB versus the time of irradiation, as shown in Figure. 13. The straight lines showing that the reactions are of pseudo-first order and the apparent rate constants were predestined as the slope of the linear regression to the data points in the plots and the values were listed in Table 5. It can be found that the reaction rate has significantly improved after doping modification compared with $\mathrm{ZnO}$ $\left(\mathrm{k}=1.97 \times 10^{-3} \mathrm{~min}^{-1}\right)$. Among them, $\mathrm{ZnO} 6.4$ at. $\% \mathrm{Mg}$ has the highest reaction rate $\left(\mathrm{k}=8.65 \times 10^{-3} \mathrm{~min}^{-1}\right)$, which confirms the faster removal of $\mathrm{MB}$ in water compared to $\mathrm{ZnO}$. The relationship between the degradation efficiency of undoped and $\mathrm{Mg}$-doped $\mathrm{ZnO}(\mathrm{Mg}: 4.9,6$ and 6.4 at. \%) films and time are spotted in Figure. 14. From these curves, it is evident that the degradation efficiency achieved $62 \%, 87 \%, 93 \%$, and $97 \%$ for $\mathrm{Mg}$ 0, 4.9, 6 and 6.4 at. \%, respectively.

Table 5 Variation of $\mathrm{k}_{\mathrm{app}}$ values as a function of $\mathrm{Mg}$ doping.

\begin{tabular}{ll}
\hline Samples & $\mathrm{k}_{\text {app }} * 10^{-3}\left(\mathrm{~min}^{-1}\right)$ \\
\hline Undoped $\mathrm{ZnO}$ & 1.97 \\
$\mathrm{Mg}-\mathrm{ZnO}(4.9$ at. \%) & 5.00 \\
$\mathrm{Mg}-\mathrm{ZnO}(6$ at. \%) & 7.23 \\
$\mathrm{Mg}-\mathrm{ZnO}(6.4$ at. \%) & 8.65 \\
\hline
\end{tabular}




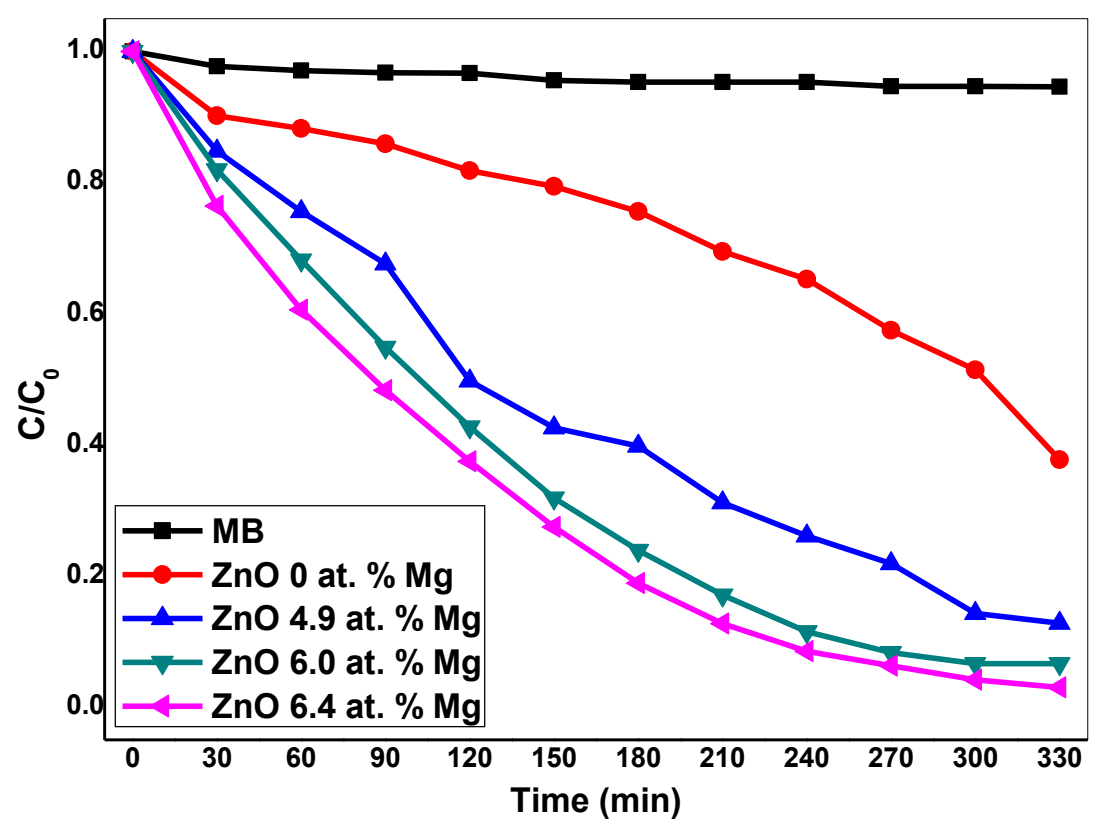

Fig. 12 the effect of the $\mathrm{Mg}$ dopant on the $\mathrm{MB}$ dye solution under irradiation of undoped and $\mathrm{Mg}$-doped $\mathrm{ZnO}$ (Mg: 4.9, 6 and 6.4 at. \%) films as a function of time.

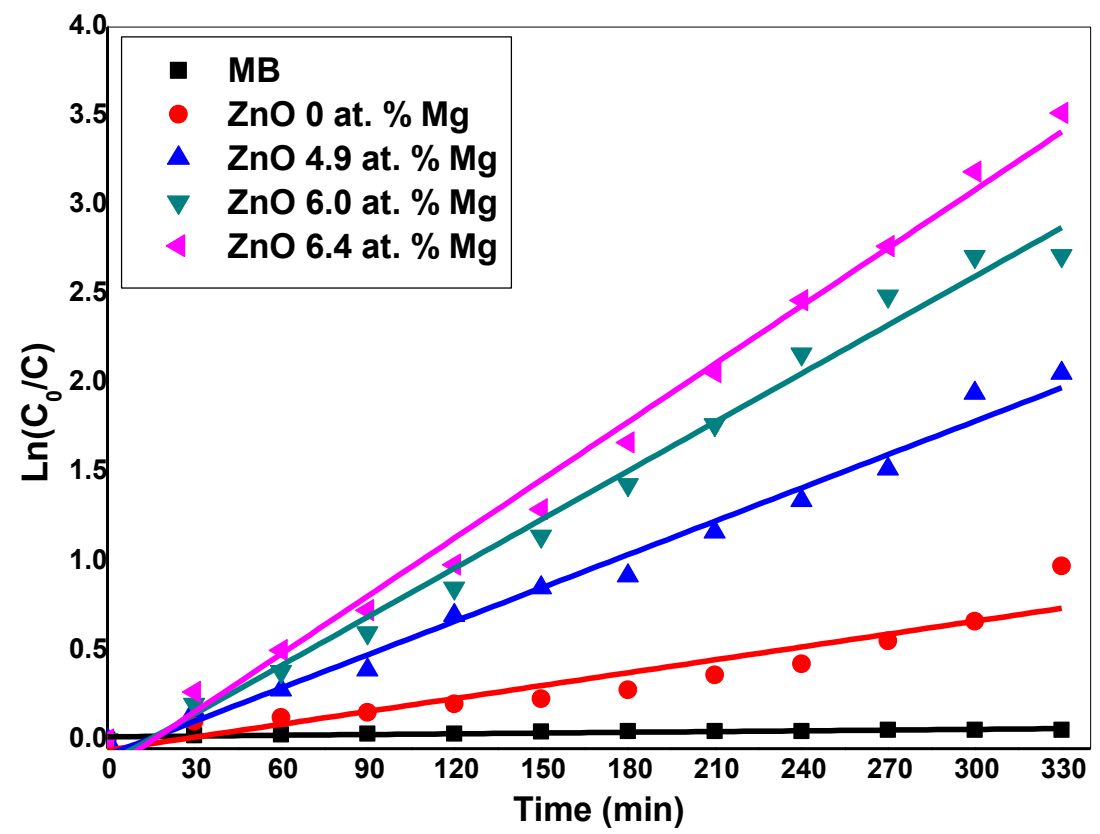

Fig. $13 \mathrm{Ln}\left(\mathrm{C}_{0} / \mathrm{C}\right)$ vs time curves of undoped and $\mathrm{Mg}$-doped $\mathrm{ZnO}(\mathrm{Mg}: 4.9,6$ and 6.4 at. \%) films as a function of time. 


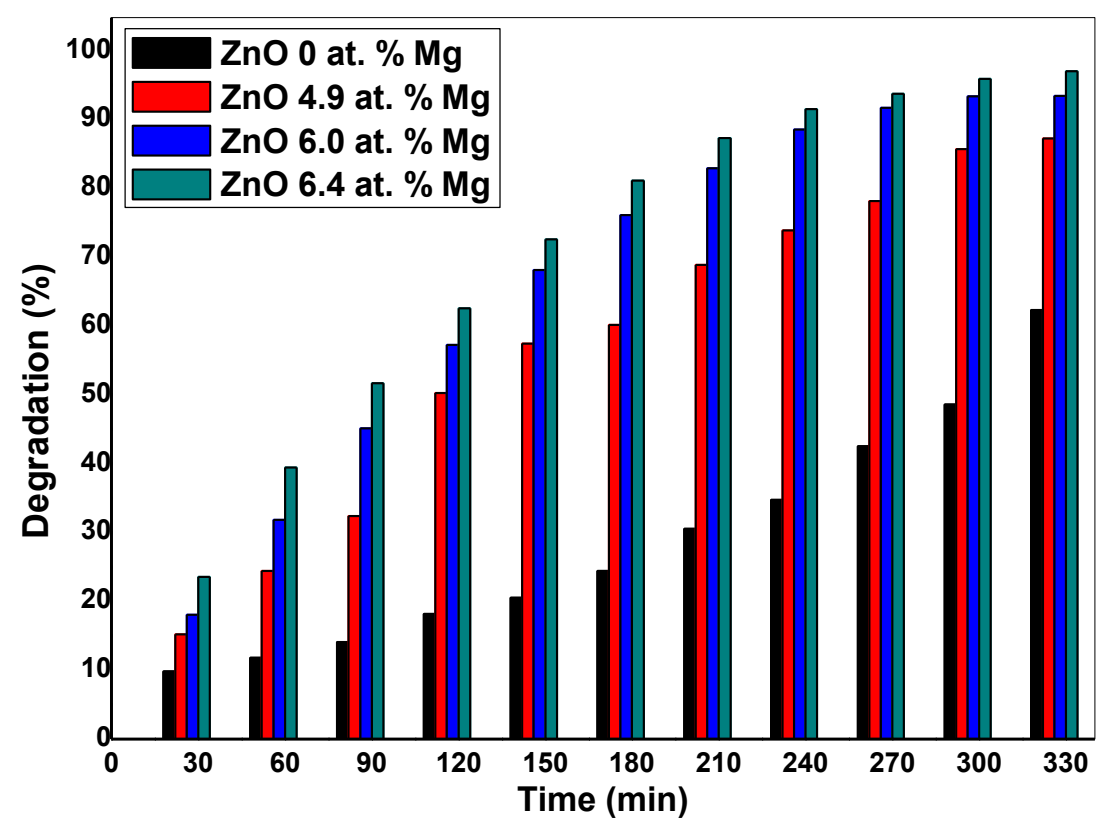

Fig. 14 Degradation efficiency of undoped and Mg-doped $\mathrm{ZnO}$ (Mg: 4.9, 6 and 6.4 at. $\%)$ films as a function of time.

The photocatalytic process is accelerated with an increase in magnesium dopant. Mg-doped $\mathrm{ZnO}$ samples display a much higher photocatalytic than undoped $\mathrm{ZnO}$, high photocatalytic degradation efficiency is observed for 6.4 at. \% $\mathrm{Mg}$-doped $\mathrm{ZnO}$. The improvement of the photocatalytic performance of $\mathrm{ZnO}$ due to $\mathrm{Mg}$ doping could be attributed to a number of factors. First, an increase in the band-gap due to $\mathrm{Mg}$ dopant causes the higher redox potential of the photo-generated electron-hole pairs, which increases the photocatalytic efficiency of the $\mathrm{Mg}$-doped $\mathrm{ZnO}$, the recombination time of electron-hole, is appropriately delayed due to the doping. Thereby, more hydroxyl radicals can be produced [16]. Benzitouni et al [37] have also reported that the increase in the band-gap of $\mathrm{ZnO}$ improve the photocatalytic due to the higher redox potential of the photo-excited pairs electron-hole.

Furthermore, the rougher surface of $\mathrm{Mg}$-doped $\mathrm{ZnO}$, exhibiting a larger specific surface area, could produce more active sites for reactant molecules to promote the efficiency of the electron-hole separation, and for the adsorption of pollutant molecules, therefore producing a higher photocatalytic [38], Jongnavakit et al. [39] have reported that the roughness surface relates to the surface area, which is an important factor that can ameliorate the photocatalytic, the photocatalytic of the $\mathrm{ZnO}$ increases with the roughness of the films. 
The equations below explained the decolorization mechanism [37]:

$\mathrm{Mg} / \mathrm{ZnO}+\mathrm{h} v \rightarrow \mathrm{Mg} / \mathrm{ZnO}\left(e_{C B}^{-}\right)+\mathrm{Mg} / \mathrm{ZnO}\left(h_{V B}^{+}\right)$

Holes react with surface bound hydroxyl groups $\mathrm{HO}^{-}$or with water $\mathrm{H}_{2} \mathrm{O}$ adsorbed on the $\mathrm{ZnO}$ surface to constitute hydroxyl radicals $\mathrm{HO}^{-}$and hydrogen ions $\mathrm{H}^{+}$, according to the equations below:

$\mathrm{Mg} / \mathrm{ZnO}\left(h_{V B}^{+}\right)+\mathrm{H}_{2} \mathrm{O} \rightarrow \mathrm{Mg} / \mathrm{ZnO}+\mathrm{OH}^{\bullet}+\mathrm{H}^{+}$

$\mathrm{Mg} / \mathrm{ZnO}\left(h_{V B}^{+}\right)+\mathrm{OH}^{-} \rightarrow \mathrm{Mg} / \mathrm{ZnO}+\mathrm{OH}^{\bullet}$

Producing superoxide anion $\mathrm{O}_{2}^{--}$by electrons are transferred to be adsorbed by oxygen $\mathrm{O}_{2}$

$\mathrm{Mg} / \mathrm{ZnO}\left(e_{C B}^{-}\right)+\mathrm{O}_{2} \rightarrow \mathrm{Mg} / \mathrm{ZnO}+{O_{2}^{--}}^{-}$

These superoxide anions $\mathrm{O}_{2}^{\cdot-}$ additionally react with adsorbed water molecules forming peroxide radicals $\mathrm{OH}_{2}^{\cdot-}$ and hydroxyl ions $\mathrm{OH}^{-}$.

$\mathrm{Mg} / \mathrm{ZnO}\left(e_{C B}^{-}\right)+\mathrm{O}_{2}^{--}+\mathrm{H}_{2} \mathrm{O} \rightarrow \mathrm{Mg} / \mathrm{ZnO}+\mathrm{OH}_{2}^{--}+\mathrm{OH}^{-}$

The peroxide radicals $\mathrm{OH}_{2}^{--}$combine with $\mathrm{H}^{+}$producing in the formation of hydroxyl radicals $\mathrm{OH}^{\circ}$ and hydroxyl ions $\mathrm{OH}^{-}$. Hydrogen peroxide is produced as an intermediate product.

$\mathrm{Mg} / \mathrm{ZnO}\left(e_{C B}^{-}\right)+\mathrm{OH}_{2}^{--}+\mathrm{H}^{+} \rightarrow \mathrm{Mg} / \mathrm{ZnO}+\mathrm{H}_{2} \mathrm{O}_{2}$

$\mathrm{Mg} / \mathrm{ZnO}\left(e_{C B}^{-}\right)+\mathrm{H}_{2} \mathrm{O}_{2} \rightarrow \mathrm{Mg} / \mathrm{ZnO}+\mathrm{OH}^{\bullet}+\mathrm{OH}^{-}$

Holes oxidize these hydroxyl ions $\mathrm{OH}^{-}$to hydroxyl radicals $\mathrm{OH}^{\bullet}$. All the species facilitate the production of $\mathrm{OH}^{\bullet}$. The strong oxidants $\mathrm{OH}^{\bullet}$ reacts with adsorbed dye molecules and perform degradation according to the reaction below:

$\mathrm{OH}^{\bullet}+$ Methylene bleu $\rightarrow$ products

The photodegradation phenomenon is concentrated on the dye oxidation/reduction through the created electrons from the semiconductor, under UVlight. 


\section{Conclusion}

In the present work, we have investigated the performance of undoped and Mg-doped $\mathrm{ZnO}(\mathrm{Mg}: 4.9,6$ and 6.4 at. \%) films for the $\mathrm{MB}$ degradation in aqueous solution. Undoped and $\mathrm{Mg}$-doped $\mathrm{ZnO}(\mathrm{Mg}: 4.9,6$ and 6.4 at. \%) films were fabricated by sol-gel process associated with dip-coating. The EDSX was confirmed the formation of $\mathrm{ZnO}$ and the presence of $\mathrm{Mg}$ dopant in $\mathrm{ZnO}$. According to structural studies, all samples exhibited the hexagonal wurtzite structure of $\mathrm{ZnO}$; the addition of $\mathrm{Mg}$ improves the film crystallinity and promotes the growth along the $\mathrm{c}$ axis of the wurtzite cell. The visible optical transmittance of all the films is between 70 and $80 \%$ in the visible range, the band-gap was increased from $3.28 \mathrm{eV}$ to $3.59 \mathrm{eV}$ with $\mathrm{Mg}$ dopant. AFM images showed that the undoped and $\mathrm{Mg}$-doped $\mathrm{ZnO}$ are composed of rounded shaped particles, the RMS roughness values increases with the increase of $\mathrm{Mg}$ dopant from 4.46 to $12.30 \mathrm{~nm}$. ESEM images showed that the undoped and $\mathrm{Mg}$ doped $\mathrm{ZnO}$ films had wrinkles morphology. PL measurements confirm the increase of the band-gap energy upon $\mathrm{Mg}$ dopant. The catalytic efficiency of $\mathrm{ZnO}$ films was improved with the Mg dopant, 97\% MB was degraded after 330 min exposure to UVlight.

\section{Acknowledgments}

The authors would like to thank Drs. Ahmed Reda Khantoul, Pascal Boulet, Badis Rahal, Thomas Gries and Alaa Eldin Giba, for help with Energy-Dispersive spectroscopy of X-ray (EDSX), X-ray diffraction analysis (XRD), Atomic Force Microscopy (AFM), Scanning Electron Microscopy (SEM) and Photoluminescence (PL) measurements. 


\section{REFERENCES}

[1] A. Balcha, O.P. Yadab, T. Dey, Photocatalytic degradation of methylene blue dye by zinc oxide nanoparticles obtained from precipitation and sol-gel methods, Environ. Sci. Pollut. Res. 23, 25485-25493 (2016)

[2] E. Muchuweni, T.S. Sathiaraj, H. Nyakotyo, Physical properties of gallium and aluminium co-doped zinc oxide thin films deposited at different radio frequency magnetron sputtering power, Ceram. Int. 42, 17706-17710 (2016)

[3] S.S. Shinde, P.S. Shinde, Y.W. Oh, D. Haranath, C.H. Bhosale, K.Y. Rajpure, Structural optoelectronic, luminescence and thermal properties of Ga-doped zinc oxide thin films, Appl. Surf. Sci. 258, 9969-9976 (2012)

[4] G.N. Narayanan, R.S. Ganesh, A. Karthigeyan, Effect of annealing temperature on structural, optical and electrical properties of hydrothermal assisted zinc oxide nanorods, Thin Solid Films. 598, 39-45 (2016)

[5] A. Kaushal, D. Kaur, Effect of Mg content on structural, electrical and optical properties of $\mathrm{Zn}_{1-x} \mathrm{Mg}_{\mathrm{x}} \mathrm{O}$ nanocomposite thin films, Sol. Energy Mater. Sol. Cells. 93, 193-198 (2009)

[6] M. Rouchdi, E. Salmani, B. Fares, N. Hassanain, A. Mzerd, Synthesis and characteristics of $\mathrm{Mg}$ doped $\mathrm{ZnO}$ thin films: Experimental and ab-initio study, Results Phys. 7, 620-627 (2017)

[7] C. de Melo, M. Jullien, Y. Battie, A. En Naciri, J. Ghanbaja, F. Montaigne, J.F. Pierson, F. Soldera, F. Rigoni, N. Almqvist, A. Vomiero, S. Migot, F. Mücklich, D. Horwat, Semi-Transparent p-Cu2O/n-ZnO Nanoscale-Film Heterojunctions for Photodetection and Photovoltaic Applications, ACS Appl. Nano Mater. 2, 4358-4366 (2019)

[8] V. Galstyan, E. Comini, C. Baratto, G. Faglia, G. Sberveglieri, Nanostructured $\mathrm{ZnO}$ chemical gas sensors, Ceram. Int. 41, 14239-14244 (2015).

[9] B.U. Haq, R. Ahmed, A. Shaari, A. Afaq, B.A. Tahir, R. Khenata, First-principles investigations of $\mathrm{Mn}$ doped zinc-blende $\mathrm{ZnO}$ based magnetic semiconductors: Materials for spintronic applications, Mater. Sci. Semicond. Process. 29, 256-261 (2015) 
[10] A. Azam, F. Ahmed, S.S. Habib, Z.H. Khan, N.A. Salah, Fabrication of Codoped $\mathrm{ZnO}$ nanorods for spintronic devices, Met. Mater. Int. 19, 845-850 (2013)

[11] E. Muchuweni, T.S. Sathiaraj, H. Nyakotyo, Effect of gallium doping on the structural, optical and electrical properties of zinc oxide thin films prepared by spray pyrolysis, Ceram. Int. 42, 10066-10070 (2016)

[12] J.-H. Lee, K.-H. Ko, B.-O. Park, Electrical and optical properties of $\mathrm{ZnO}$ transparent conducting films by the sol-gel method, J. Cryst. Growth. 247, 119-125 (2003)

[13] S.I. Shimakawa, Y. Hashimoto, S. Hayashi, T. Satoh, T. Negami, Annealing effects on $\mathrm{Zn}_{1-\mathrm{x}} \mathrm{Mg}_{\mathrm{x}} \mathrm{O} / \mathrm{CIGS}$ interfaces characterized by ultraviolet light excited timeresolved photoluminescence, Sol. Energy Mater. Sol. Cells. 92, 1086-1090 (2008)

[14] H. Wang, G. Yi, X. Zu, P. Qin, M. Tan, H. Luo, Photoelectric characteristics of the $\mathrm{p}-\mathrm{n}$ junction between $\mathrm{ZnO}$ nanorods and polyaniline nanowires and their application as a UV photodetector, Mater Lett. 162, 83-86 (2016)

[15] S. Fernández, J.D. Santos, C. Munuera, M.G. Hernández, F.B. Naranjo, Effect of argon plasma-treated polyethylene terepthalate on $\mathrm{ZnO}: \mathrm{Al}$ properties for flexible thin film silicon solar cells applications, Sol. Energy Mater. Sol. Cells. 133, 170-179 (2015)

[16] M. R. Islam, M. G. Azam, Enhanced photocatalytic activity of Mg-doped ZnO thin films prepared by sol-gel method, Surf. Eng. (2020). https://doi.org/ $10.1080 / 02670844.2020 .1801143$

[17] L. Xue, L. Xaing, L. Peng-Ting, C. Xing-Wang, L. Ying, C. Chuan-Bao, Mg doping reduced full width at half maximum of the near-band-edge emission in $\mathrm{Mg}$ doped ZnO films, Chin. Phys. B. 19, 027202(2010)

[18] G. El Hallani, S. Nasih, N. Fazouan, A. Liba, M. Khuili, M. Sajieddine, M. Mabrouki, L. Laanab, E.H. Atmani, Comparative study for highly Al and Mg doped $\mathrm{ZnO}$ thin films elaborated by sol gel method for photovoltaic application, Appl. Phy. $121,135103(2017)$ 
[19] M. Toubane, R. Tala-Ighil, F. Bensouici, M. Bououdina, M. Souier, S. Liu, W. Cai, A. Iratni, Sol Concentration effect on $\mathrm{ZnO}$ nanofibs Photocatalytic Activity Synthesized by Sol-Gel Dip Coating Method, Mater. Res. Express. 4, 035023 (2017)

[20] S. Kurtaran, S. Aldag, G. Ofofoglu, I. Akyuz, F. Atay, Transparent conductive $\mathrm{ZnO}$ thin films grown by chemical spray pyrolysis: the effect of $\mathrm{Mg}$, J. Mater. Sci: Mater. Electron. 27, 8478-8485 (2016)

[21] S. Lemlikchi, S. Abdelli-Messaci, S. Lafane, T. Kerdja, A. Guittoum, M. Saad, Study of structural and optical properties of $\mathrm{ZnO}$ films grown by pulsed laser deposition, Appl. Surf. Sci. 256, 5650-5655 (2010)

[22] M. Caglar, S. Ilican, Y. Caglar, F. Yakuphanoglu, Electrical conductivity and optical properties of $\mathrm{ZnO}$ nanostructured thin film, Appl. Surf. Sci. 255, 4491-4496 (2009)

[23] M. Han, Z. Dong, J. Liu, G. Ren, M. Ling, X. Yang, L. Zhang, B. Xue, F. Li, The role of lanthanum in improving the visible-light photocatalytic activity of $\mathrm{TiO} 2$ nanoparticles prepared by hydrothermal method, Appl. Phy. A. 950, 126 (2020)

[24] S. Vignesh, J.K. Sundar, Investigations of visible light driven $\mathrm{Sn}$ and $\mathrm{Cu}$ doped $\mathrm{ZnO}$ hybrid nanoparticles for photocatalytic performance and antibacterial activity, Appl. Surf. Sci. 449, 617-630 (2018)

[25] R. Ghosh, D. Basak, Composition dependence of electrical and optical properties in sol-gel $\mathrm{Mg}_{\mathrm{x}} \mathrm{Zn}_{1-\mathrm{x}} \mathrm{O}$ thin films, Appl. Phys. 101, 023507 (2007)

[26] C. Abed, S. Fernández, H. Elhouichet, Studies of optical properties of ZnO:MgO thin films fabricated by sputtering from home-made stable oversize targets, Optik. 216, 164934 (2020)

[27] Y. Hu, B. Cai, Z. Hu, Y. Liu, S. Zhang, H. Zeng, The impact of Mg content on the structural, electrical and optical properties of $\mathrm{MgZnO}$ alloys: A first principles study, Curr. Appl. Phys. 15, 423-428 (2015)

[28] B. Rahal, B. Boudine, N. Souami, M. Siad, M. Sebais, O. Halimi, L. Guerbous, Behavior Study of the Nanostructured $\mathrm{Zn1-xCdxO}(0 \leq x \leq 0.1)$ Semiconductor Thin Films Deposited onto Silicon Substrate by Dip-Coating Method, Silicon. 12, $2967-$ 2976 (2020) 
[29] M. Han, Z. Dong, J. Liu, G. Ren, M. Ling, X. Yang, Lianren Zhang, B. Xue, F. $\mathrm{Li}$, The role of lanthanum in improving the visible-light photocatalytic activity of TiO2 nanoparticles prepared by hydrothermal method, Appl. Phys. A. 950, 126 (2020)

[30] W. Chamorro, D. Horwat, P. Pigeat, P. Miska, S. Migot, F. Soldera, P. Boulet F. Mücklich, Near-room temperature single-domain epitaxy of reactively sputtered $\mathrm{ZnO}$ films, J. Phys. D: Appl. Phys. 46, 235107 (2013)

[31] M. Rouchdi, E. Salmani, A. El Hat, N. Hassanain, A. Mzerd, Synthesis magnetic properties of Ni-doped $\mathrm{ZnO}$ thin films : experimental and AB initio study, Surf. Rev. Lett. 24, 1750085 (2017)

[32] S. Handani, Emriadi, D. Dahlan, S. Arief, Enhanced structural, optical and morphological properties of $\mathrm{ZnO}$ thin film using green chemical approach, Vacuum. $179,109513(2020)$

[33] K. Huang, Z. Tanga, L. Zhanga, J. Yua, J. Lvb, X. Liuc, F. Liud, Preparation and characterization of $\mathrm{Mg}$-doped $\mathrm{ZnO}$ thin films by sol-gel method, Appl. Surf. Sci. 258, 3710-3713 (2012)

[34] S. Fujita, H. Tanaka, MBE growth of wide band gap wurtzite $\mathrm{MgZnO}$ quasialloys with $\mathrm{MgO} / \mathrm{ZnO}$ superlattices for deep ultraviolet optical functions, J. Cryst. Growth. 278, 264-267 (2005)

[35] Y. Fan, T. Ai, W. Li, Z. Deng, X. Yuan, Photoluminescence Properties of Indium-doped $\mathrm{ZnO} / \mathrm{Cu}$-graphene Thin Films Synthesized by Hydrothermal Method, Sens. Mater. 31, 1357-1364 (2019)

[36] N.A. Putri, V. Fauzia, S. Iwan, L. Roza, A.A. Umar, S. Budi, Mn-dopinginduced photocatalytic activity enhancement of $\mathrm{ZnO}$ nanorods prepared on glass substrates, Appl. Surf. Sci. 439, 285-297 (2018)

[37] S. Benzitouni, M. Zaabat, M.S. Aida, J. Ebothe, J. Michel, B. Boudine, L. Mansouri, T. Saidani, Morphology and photocatalytic activity of porous (In, Mg) codoped $\mathrm{ZnO}$ nanoparticles, Optik. 156, 949-960 (2017)

[38] B. Yin, S. Zhang, D. Zhang, Y. Jiao, Y. Liu, F. Qu, Xi. Wu, ZnO Film Photocatalysts, J. Nanomater. 7 (2014) 
[39] P. Jongnavakit, P. Amornpitoksuk, S. Suwanboon, T. Ratana, Surface and photocatalytic properties of $\mathrm{ZnO}$ thin film prepared by sol-gel method, Thin Solid Films. 520, 5561-5567 (2012) 


\section{Declarations:}

Funding info: No funding was received to assist with the preparation of this manuscript.

Competing interests: The authors have no conflicts of interest to declare that are relevant to the content of this article.

Author contribution: All authors conceived and designed the study. Imene Ameur conducted the experiments. All authors contributed to manuscript revisions. All authors approved the final version of the manuscript and agree to be held accountable for the content therein.

Conceptualization: Boubekeur BOUDINE and Imene AMEUR; Methodology: Boubekeur BOUDINE and Imene AMEUR; Formal analysis and investigation: All authors; Writing-original draft preparation: All authors; Writing - review and editing: All authors; Funding acquisition: All authors; Resources: All authors; Supervision: Boubekeur BOUDINE.

Availability of data and materials: Not applicable

Code availability: Not applicable. 
